\title{
Augmented Reality in Education: An Overview of Twenty-Five Years of Research
}

\author{
Cecilia Avila-Garzon \\ Fundación Universitaria Konrad Lorenz, Faculty of Mathematics and Engineering, Bogotá, Colombia \\ ORCID: 0000-0002-2384-0518 \\ Jorge Bacca-Acosta \\ Fundación Universitaria Konrad Lorenz, Faculty of Mathematics and Engineering, Bogotá, Colombia \\ ORCID: 0000-0003-0381-6972 \\ Kinshuk \\ University of North Texas, College of Information, Denton, USA \\ ORCID: 0000-0003-3923-9003 \\ Joan Duarte \\ Fundación Universitaria Konrad Lorenz, Faculty of Mathematics and Engineering, Bogotá, Colombia \\ ORCID: 0000-0002-6285-6926 \\ Juan Betancourt \\ Fundación Universitaria Konrad Lorenz, Faculty of Mathematics and Engineering, Bogotá, Colombia \\ ORCID: 0000-0003-2351-2693
}

Received: 8 Jul 2020

Accepted: 3 Feb 2021

\begin{abstract}
Research on augmented reality (AR) in education is gaining momentum worldwide. This field has been actively growing over the past decades in terms of the research and development of new technologies. Reviews in the field of AR in education consist of systematic literature reviews and meta-analyses (around 45), surveys (around 33), and only one bibliometric analysis. However, these reviews do not provide a general synthesis of the research published in the field to depict its evolution over the years. This study used the metadata of articles from a 25 -year period (1995-2020) to conduct a bibliometric analysis. A total of 3,475 studies were considered. In this study, we used tools such as the Scopus database, the bibliometrix R package, and the VOSviewer analysis tool. The analysis of the literature is based on the metadata, author, content, and citation information extracted from the dataset. In addition, we focus on comparing literature published mainly in journals (articles, articles in press, and reviews) and those published in other sources (conference papers, books, and book chapters). Practitioners could use the results of this study to make decisions about the adoption of AR technologies in education.
\end{abstract}

Keywords: augmented reality, education, learning, bibliometric, trends

\section{INTRODUCTION}

In the field of educational technology, there is a wide variety of technologies and approaches being used around the world to provide better support for teaching and learning processes. Among these approaches, augmented reality (AR) is a technology that is gaining momentum around the globe. AR allows users to see 
the real world with digital information superimposed (Azuma, 1997). AR has been an active area of research in the educational setting as a supporting technology for learning and teaching processes. AR has attracted a lot of interest in the research community because it provides unique learning experiences that cannot be achieved using other technologies or approaches. AR offers new forms of interactivity with content, improved visualisations of scientific phenomena, and a reduced cognitive load. Many AR applications have been developed for a wide variety of learning domains, such as science, engineering, and social sciences (Cipresso et al., 2018; Garzón \& Acevedo, 2019). Research on AR in education has demonstrated that AR has a positive effect on students' learning outcomes (Akçayır \& Akçayır, 2017; Bernal et al., 2019; Cano et al., 2019; Radu, 2014) and motivation (Arici et al., 2019; Bacca et al., 2018; Chiang et al., 2014; Ibañez et al., 2020). In their meta-analysis of the effectiveness of AR in education, Tekedere and Göker (2016) found a medium effect size (0.67) of AR on education. Likewise, Garzón et al. (2020) found a medium effect size (0.72) of AR on students' learning gains. According to the EDUCAUSE Horizon Report, Extended Reality (XR) technologies (a concept that includes AR) seem to be 'an effective way to augment traditional forms of pedagogy' (Brown et al., 2020, p. 30).

This study aims to conduct a bibliometric analysis in the field of AR in education. While there are many systematic reviews and meta-analyses on AR in education and related topics, such as those conducted by Akçayır and Akçayır (2017), and Garzón and Acevedo (2019) to name just a couple, the existing reviews are very narrow in the sense that they only cover a small sample of articles published in the field and a narrow timeframe. In other cases, some of the reviews have only considered journal articles to the exclusion of conference papers and other documents. In other cases, systematic reviews might be biased due to researchers' personal views and interpretations or due to errors introduced from the content itself. These constraints limit the conclusions that can be drawn from and the synthesis of research in the field, making the decision-making process related to research in this field more difficult.

Bibliometric analyses differ from systematic reviews and meta-analyses in the sense that a bibliometric analysis is more objective and reliable given that it entails a structured analysis of a very large body of information based on statistical analysis. With a bibliometric analysis, many types of articles can be considered and broadly analysed to draw accurate conclusions about the dynamics of research in the field. A bibliometric analysis might benefit other researchers who are looking for trending topics in the field and might also benefit policymakers (Aria \& Cuccurullo, 2017) who make decisions on the creation of funding opportunities and define plans for the implementation of technologies in education. Furthermore, bibliometric analysis is key to mapping the state of the art of a particular field (Oliveira et al., 2019).

The analysis presented in this study addresses journal articles and other types of papers, such as conference papers, books, and book chapters (a total of 3,475 studies were considered). The research questions that this study aims to answer are as follows:

- RQ1: How has AR in education evolved in terms of annual scientific growth, the countries that contribute the most, and the most relevant publication sources?

- RQ2: Who are the authors that have contributed the most to AR in education as measured by the number of publications and citations per year?

- RQ3: What are the future research directions in AR in education?

This article's main contribution is that it provides a general landscape of the research on AR in education, showing how research in this field has evolved over the last 25 years and identifying the authors who have contributed the most as well as trending topics. This information might be of special interest to researchers, so that they can focus on the hottest topics in the field. Moreover, funding agencies can identify key areas for grants and other funding opportunities.

\section{RELATED WORK}

In the literature on AR in education, there are other bibliometric analyses that are focused on particular topics such as physical education (Calabuig-Moreno et al., 2020), the sustainability of AR in higher education 
(Abad-Segura et al., 2020), and research on AR in higher education (López et al., 2019). In the field of science education, Arici et al. (2019) conducted a bibliometric analysis of 147 articles and a systematic review of 79 articles published between 2013 and 2018. Karakus et al. (2019) conducted a bibliometric analysis of 437 journal articles from the Web of Science (WOS), but conference papers were not considered. Bhagat (2019) conducted a bibliometric analysis of 1,737 articles related to AR in simulation and training. There is also another bibliometric analysis that considered $A R$ from a general perspective, but it is not focused on education (Cipresso et al., 2018). Collectively, these analyses reflect increasing interest in AR technology around the world and the fact that related scientific production is also increasing.

Apart from conducting a bibliometric analysis, we also evaluated the state of the field by examining published systematic reviews, meta-analyses, and surveys on the topic. This information is useful for researchers, practitioners, and other stakeholders because we provide a summary of the current systematic reviews, meta-analyses, and surveys in the field, so that stakeholders can refer to them when they need specific information about a particular topic within the field. To do that, we searched the Scopus database using the following string: ( TITLE-ABS-KEY ( "augmented reality") AND TITLE-ABS-KEY ( educat*) AND TITLE-ABS-KEY ("systematic literature review") OR TITLE-ABS-KEY ("systematic review") OR TITLE-ABS-KEY ("metaanalysis" ) OR TITLE-ABS-KEY ("survey") ) for three types of articles: systematic literature reviews, metaanalyses, and surveys conducted in the field of $A R$ in education. This search yielded 128 results. We analysed the abstract of each result to identify whether the article belongs to any of the three types of articles of interest and to the field of AR in education. After removing duplicates, we revised each article to identify its type. As a result, we found 45 systematic literature reviews and meta-analyses and 33 surveys published in the field of $A R$ in education. We read the articles, and for each literature review and meta-analysis, we extracted the following data: type of paper (journal or conference paper), title, year of publication, source of publication, type of review (systematic or meta-analysis), main topic, number of studies considered, type(s) of paper(s) reviewed in the article, and coverage (timeframe). Table A.1 in Appendix A presents the information collected for the 44 systematic literature reviews, and Table A.2 in Appendix A presents the information collected for the 33 surveys. It is important to note that Table A.2 in Appendix A does not provide information about the number of studies considered, the types of papers reviewed in the survey, and coverage (timeframe) because most of the surveys do not provide this information, as these surveys are not systematic in nature.

Overall, the results show that there has been an increase in the number of systematic literature reviews in the field of $A R$ in education. For instance, to date, seven systematic literature reviews have been published in 2019, and for 2018, we found that 14 systematic literature reviews were published. This is a positive result because it reveals researchers' interest in uncovering the benefits, advantages, and potentialities of this technology in education. However, most of these literature reviews were conducted in a particular field, such as science education, informal education, STEM education, and game-based learning, among others. Consequently, the findings of these literature reviews provide a narrow overview of particular areas of interest but do not provide a general overview of the current state of research on AR in education. The primary benefit of taking education as a whole and see how AR has been used in this field is that a general overview of the field might help to identify trends in research, emergent topics and topics that have not been explored yet. A bibliometric analysis of AR in education as a whole field may uncover trends, strategic areas for research, current research problems, the potential impact of certain research areas within the field and the expansion of knowledge in that field (Oliveira et al., 2019) as well as the quality of research in that field (Bornmann \& Leydesdorff, 2014). These outputs are difficult to be obtained from systematic reviews. Moreover, a bibliometric analysis is useful for evaluating the quality of research. Thus, there is a need to identify the current state of global research on AR in education from a more general perspective in order to identify areas that need further research, communities of researchers for collaboration, and trending topics. In order to contribute to filling this gap, this paper reports on a bibliometric analysis of research in the field of AR. Although a general overview of the field is too broad to cover, a bibliometric analysis is a suitable technique to examine the current state of research in a broad field (Ellegaard \& Wallin, 2015). The bibliometric analysis presented in this article supplements the state of research reported in systematic reviews that have focused on particular areas or domains of AR application. In this article, researchers, 
practitioners, and policymakers interested in this technology can gain a general overview of the current state of research, trending topics, and future research directions; they can also refer to the systematic literature reviews listed in Appendix A for more specific information about particular fields of application.

\section{METHODOLOGY}

\section{Bibliometric Analysis}

In the scientometrics field, bibliometric analysis is defined as statistical analysis for providing a quantitative analysis of information from different written sources (books, articles, etc.) (Ellegaard \& Wallin, 2015). Bibliometric analysis has been adopted by many studies in the fields of education (Fellnhofer, 2019; Li et al., 2019), economics (Wei, 2019), psychology (Zyoud et al., 2018), and biology (Yang \& Wu, 2017), among others. It can be used to obtain a general and detailed overview of the literature and map the state of the art in a research field (Oliveira et al., 2019). Moreover, the development of tools for conducting bibliometric analyses has been growing, and some research databases use bibliometric information for filtering results and obtaining different types of visualisations. In this study, we used bibliometrix (Aria \& Cuccurullo, 2017), which is an R package for mapping analysis based on scientific literature, the filtering options from the Scopus database, and the VOSviewer analysis tool. The options used from each tool are described as follows:

- Bibliometrix: analysis of contributions (years, authors, countries), author's keywords analysis, trending topics, sankey diagram and co-citation network.

- VoSViewer: analysis of keywords with a word cloud.

\section{Inclusion and Exclusion Criteria}

Unlike the existing systematic reviews and other bibliometric analyses, which only considered one type of scientific document (i.e. journal articles or conference papers), in this bibliometric analysis, we included journal articles, conference papers, books, and book chapters about AR in education that are indexed in Scopus. The inclusion of all of these types of documents allowed us to gather a more complete sample to conduct the bibliometric analysis; we therefore have a more accurate landscape of research in the field. Moreover, since these types of documents usually go through peer review before publication and indexing in Scopus, they are more reliable for analysis. Thus, the inclusion criteria are as follows:

- Journal articles, reviews, conference papers, books, and book chapters that are indexed in Scopus, have a clear focus on AR in education, and are written in English.

Regarding the exclusion criteria, we did not include the following types of documents:

- Book reviews, notes, erratum, editorials, letters to the editor, doctoral theses, master's dissertations, and other non-scientific documents.

\section{Article Information Retrieval and Filtering}

We used the Scopus database for this bibliometric analysis because it is one of the largest abstract and citation databases and the quality of its indexed publications is high. Moreover, other bibliometric analysis have focused in other databases such as Web of Science but very few focused on Scopus. After searching in the Scopus database using the search query: ( TITLE-ABS-KEY ("augmented reality") AND TITLE-ABS-KEY ( educ*) ) AND PUBYEAR < 2020, a dataset consisting of 3,712 records was obtained. After applying inclusion and exclusion criteria, a total of 3,475 papers were considered. The results obtained were exported into a BibTeX file, including citation information (author(s), document title, year, source title, volume, issue, pages, citation count, source, document type, and DOI), bibliographic information (affiliations, serial identifiers, publisher, editor(s), correspondence address, and abbreviated source title), abstracts, keywords (author and index keywords), and references. Duplicated entries in the BibTeX file were removed using BibTooL (Charalampos, 2020). The BibTeX file was loaded into bibliometrix to analyse bibliometric information, such as scientific production, sources, authors, content, thematic evolution, co-citation, and collaboration. 
Table 1. Number of studies by group

\begin{tabular}{cccc}
\hline & Group A & \multicolumn{2}{c}{ Group B } \\
\hline Document type & Number of studies & Document type & Number of studies \\
\hline Article & 1,077 & Conference paper & 2,128 \\
Reviews & 96 & Book chapter & 162 \\
& & Book & 12 \\
\hline Total & 1,173 & Total & 2,302 \\
\hline
\end{tabular}

Table 2. Dataset information

\begin{tabular}{lcc}
\hline Description & Results in Group A & Results in Group B \\
\hline Documents & 1,173 & 2,302 \\
Sources (journals, books, etc.) & 610 & 929 \\
Keywords plus & 3,981 & 8,921 \\
Authors' keywords & 2,694 & 4,104 \\
Period & $1998-2020$ & $1995-2020$ \\
Average citations per document & 14.47 & 4.07 \\
Authors & 3,557 & 6,111 \\
Author appearances & 4,279 & 8,135 \\
Authors of single-authored documents & 133 & 168 \\
Authors of multi-authored documents & 3,424 & 5,943 \\
Single-authored documents & 140 & 202 \\
Documents per author & 0.33 & 0.377 \\
Authors per document & 3.03 & 2.65 \\
Co-authors per document & 3.65 & 3.53 \\
Collaboration index & 3.31 & 2.83 \\
\hline
\end{tabular}

Since most of the existing literature reviews have focused exclusively on journal articles, this study broadens the scope by including and comparing other types of documents. The results obtained were then divided into two groups, which resulted in two separate BibTeX files. Group A contains journal articles and reviews, whereas Group B contains studies published as other types of documents, namely conference papers, books, and book chapters. The documents were divided into these two groups because they are different in nature. Journal articles contain a more elaborate analysis, discussion, and a stronger background compared to conference papers, but their publication process is slow. Conference papers contain more recent research and novel methods because their publication is faster. Table 1 shows the number of studies in each group according to the type of document. According to the information in the table, the number of documents published in Group B is larger than that in Group A. This means that most of the studies on AR in education have been published as conference papers, books, and book chapters.

\section{METADATA ANALYSIS}

\section{General Description of the Dataset}

Table 2 shows the main information for the dataset. It provides an overview of the documents, keywords, authors, citations, and collaborations in both groups. Although the number of documents in Group B is larger than that in Group A, Group A has a higher average number of citations per document $(14.47$, compared with Group B, which has an average of 4.07). This means that authors prefer citing mainly journal articles instead of articles published in other sources.

\section{Annual Scientific Production}

The annual growth rate for Group A was $21.6 \%$, which is quite similar to that of Group B (22.8\%). Figure 1 depicts the number of papers published per year in each group. The period 2013-2019 had the highest productivity in Group A, with more than 50 papers published per year. However, the highest productivity period in Group B was 2010-2019, with more than 50 papers published per year. The most productive year 


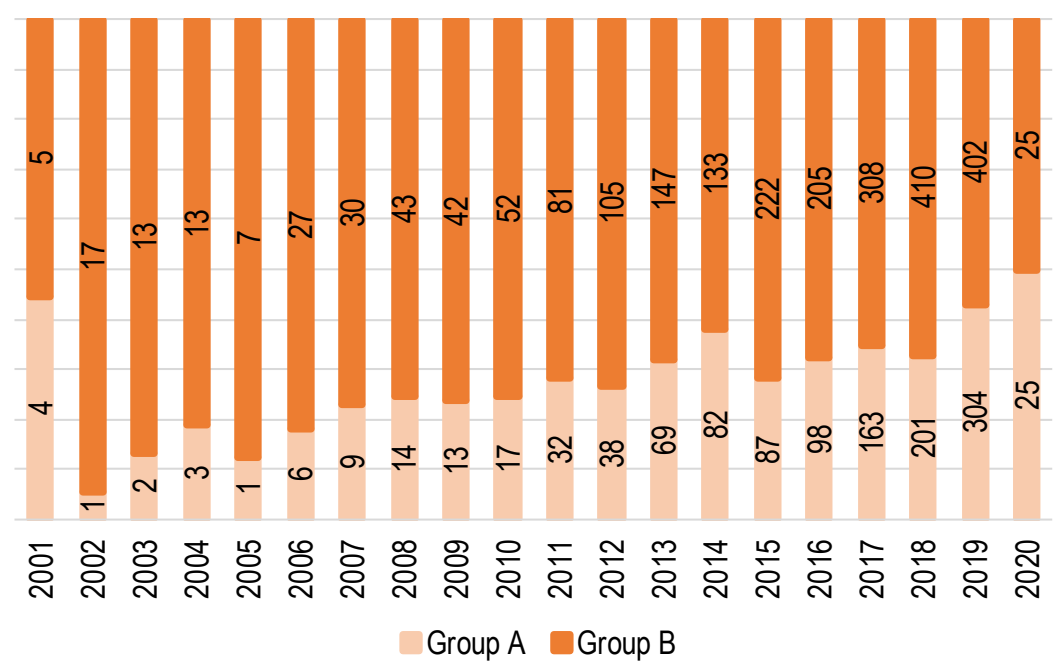

Figure 1. Annual scientific production

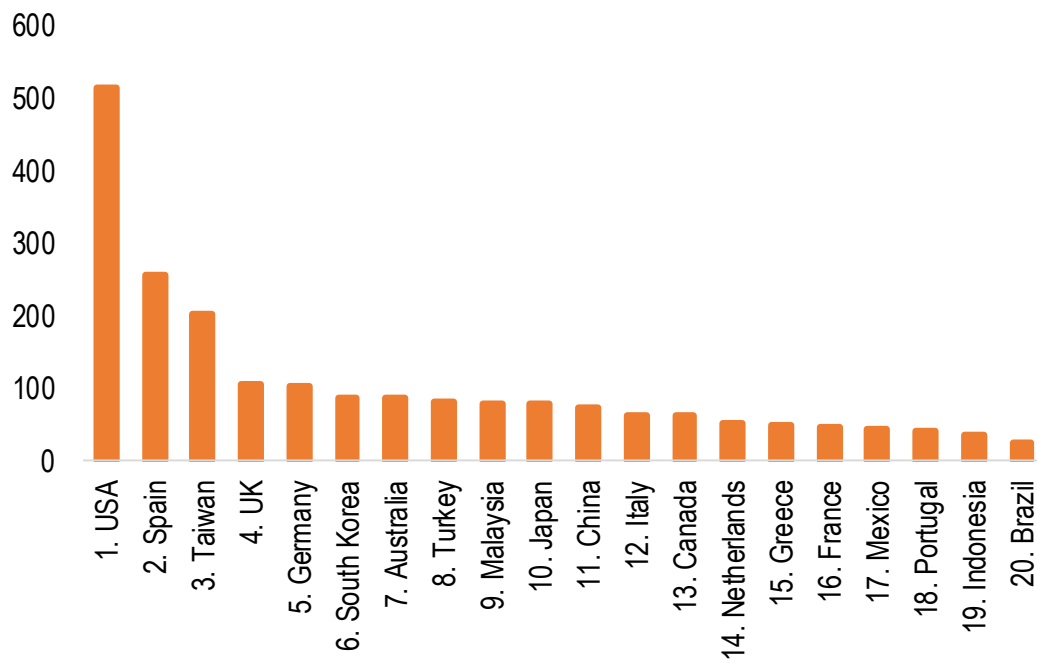

Figure 2. Scientific production by country - Group A

was 2019 for both groups $(A=304$ and $B=402)$, which demonstrates how research interest in this field has grown in recent years. However, because the dataset information was retrieved at the end of January 2020, the number of papers for 2020 is fewer in comparison to the last 10 years.

\section{Scientific Production by Country}

With regard to scientific production by country, 66 countries reported contributions in Group A and 83 in Group B. Moreover, the most productive countries are similar for both Groups $A$ and $B$. Figures $\mathbf{2}$ and $\mathbf{3}$ depict the top 20 countries for Groups $A$ and $B$, respectively. The United States $(A=514, B=558)$, Spain $(A=257, B$ $=256)$, Taiwan $(A=202, B=220)$, the United Kingdom $(A=107, B=158)$, Germany $(A=103, B=205)$, Australia $(A=86, B=158)$, Turkey $(A=82, B=63)$, Malaysia $(A=80, B=118)$, Japan $(A=79, B=164)$, and China $(A=$ $73, B=177)$ are among the top 20 in both groups.

As part of examining scientific production by country, we also identified the countries that have been conducting research in AR in education for some time and the countries that started to do research in the field in more recent years. Figure 4 shows the countries that are more active in research in this field. The countries coloured light purple or light blue, such as the United States, Spain, Taiwan, the United Kingdom, and Germany, are those that contributed to the field before 2014 and earlier. The countries coloured green or yellow, such as Mexico, Malaysia, India, Indonesia, and Colombia, began contributing to the field since 2017. 


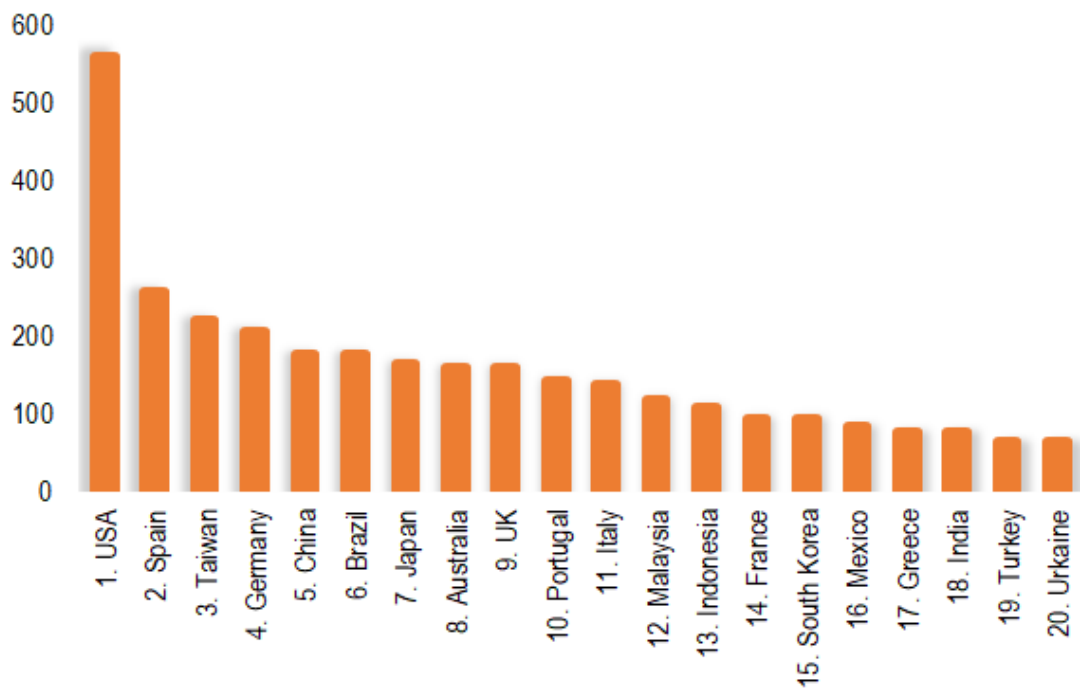

Figure 3. Scientific production by country - Group B

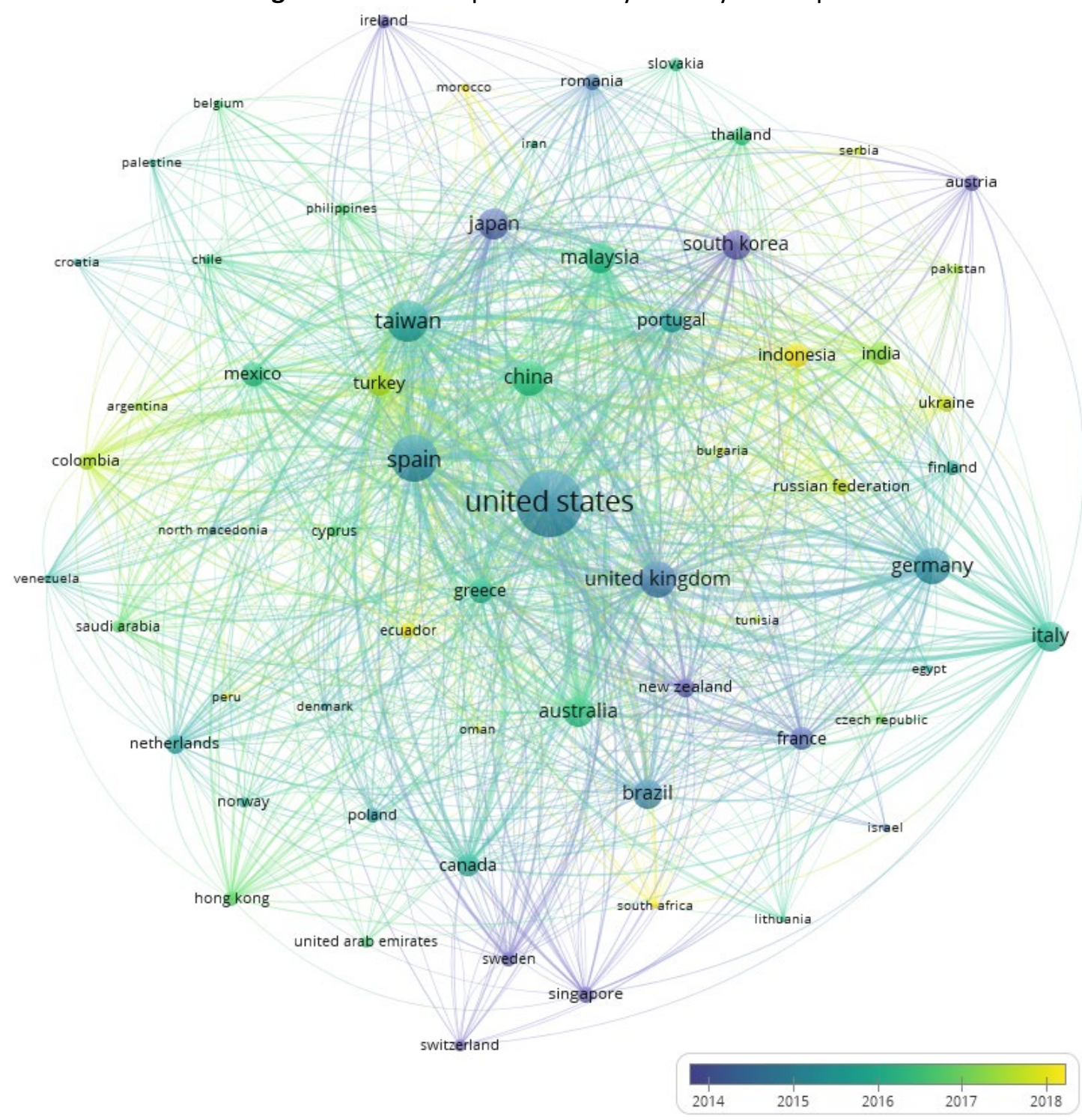

Figure 4. Contributions to the field by country and year 


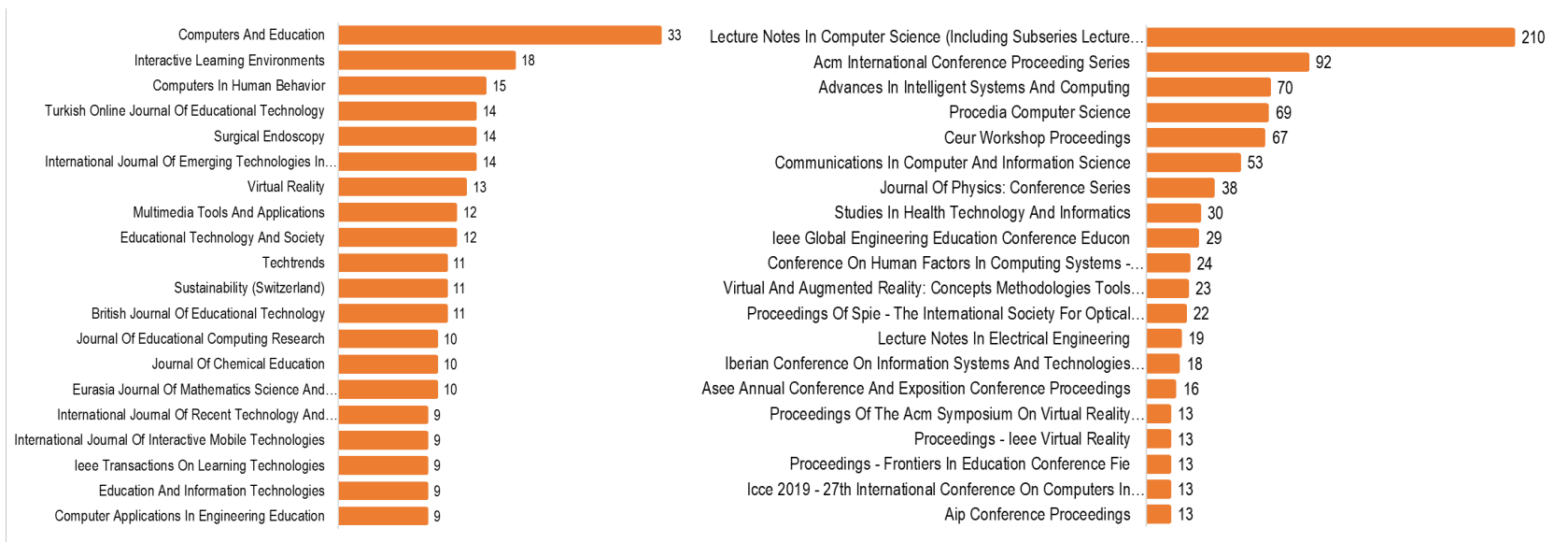

Figure 5. Top 20 relevant sources

\section{The Most Relevant Sources}

It is worth noting that several journals, books, and conferences have contributed to the publication of 2,903 papers, which have, in turn, contributed to making AR in education a trending novel topic. Figure $\mathbf{5}$ shows the top 20 sources in each group. In Group A, most of the sources are focused on education, with Computers and Education (33), Interactive Learning Environments (18), and Computers in Human Behavior (15) being the most preferred publication sources for journal articles. Moreover, from that list, Virtual Reality (13) is a specialised journal focused on virtual reality (VR), AR, and mixed reality technologies and their applications in multidisciplinary contexts.

In Group B, the sources that published the most papers per the criteria of this study are Lecture Notes in Computer Science (210), ACM International Conference Proceedings (92), and Procedia Computer Science (69).

\section{ANALYSIS OF AUTHORS}

\section{The Authors Who Have Contributed the Most Over Time}

This section describes the most relevant authors' productivity over time as measured by each author's number of publications and citations in journal articles as well as in conference papers, books, and book chapters. This productivity information is presented for the top ten authors for each type of publication in Figures $\mathbf{6}$ (Group A) and $\mathbf{7}$ (Group B). The larger the circle, the higher the number of publications, and the darker the circle, the higher the number of citations per year. It is important to note that this analysis does not consider the most cited article in the field. Instead, it considers authors' productivity in terms of publication quantity and the number of citations received. Thus, by analysing each author's number of citations per year, the most influential authors in AR in education are as follows. The most cited author in Group A is Squire (last position in Figure 6) in 2007, with a total of 447 citations and an average of 31.9 citations per year. The most cited author in any one year for Group B is Kaufmann (14th position in Figure 7) in 2003 , with a total of 268 citations and an average of 17.8 citations per year. 


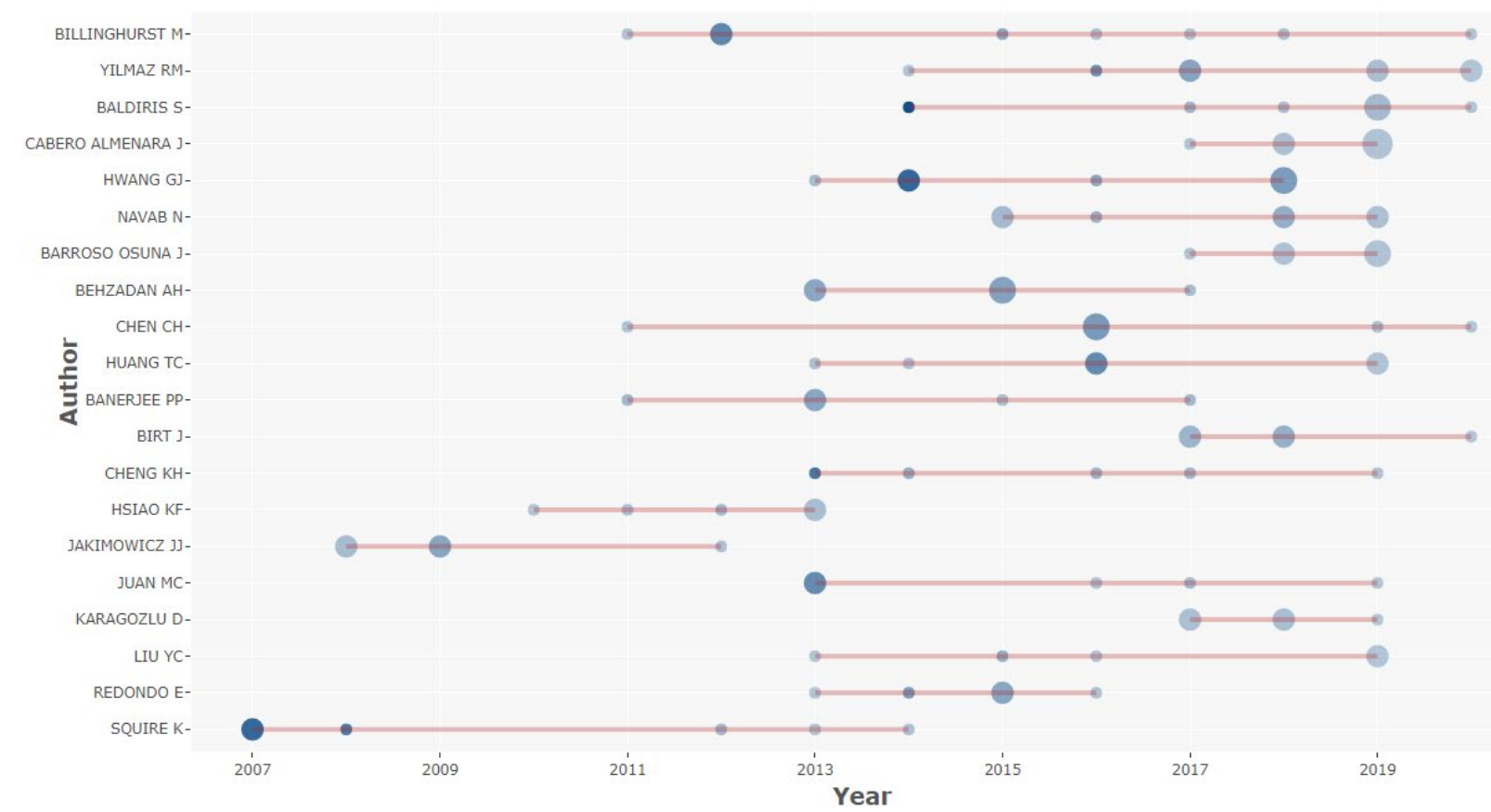

Figure 6. The top ten authors' production over time - Group A

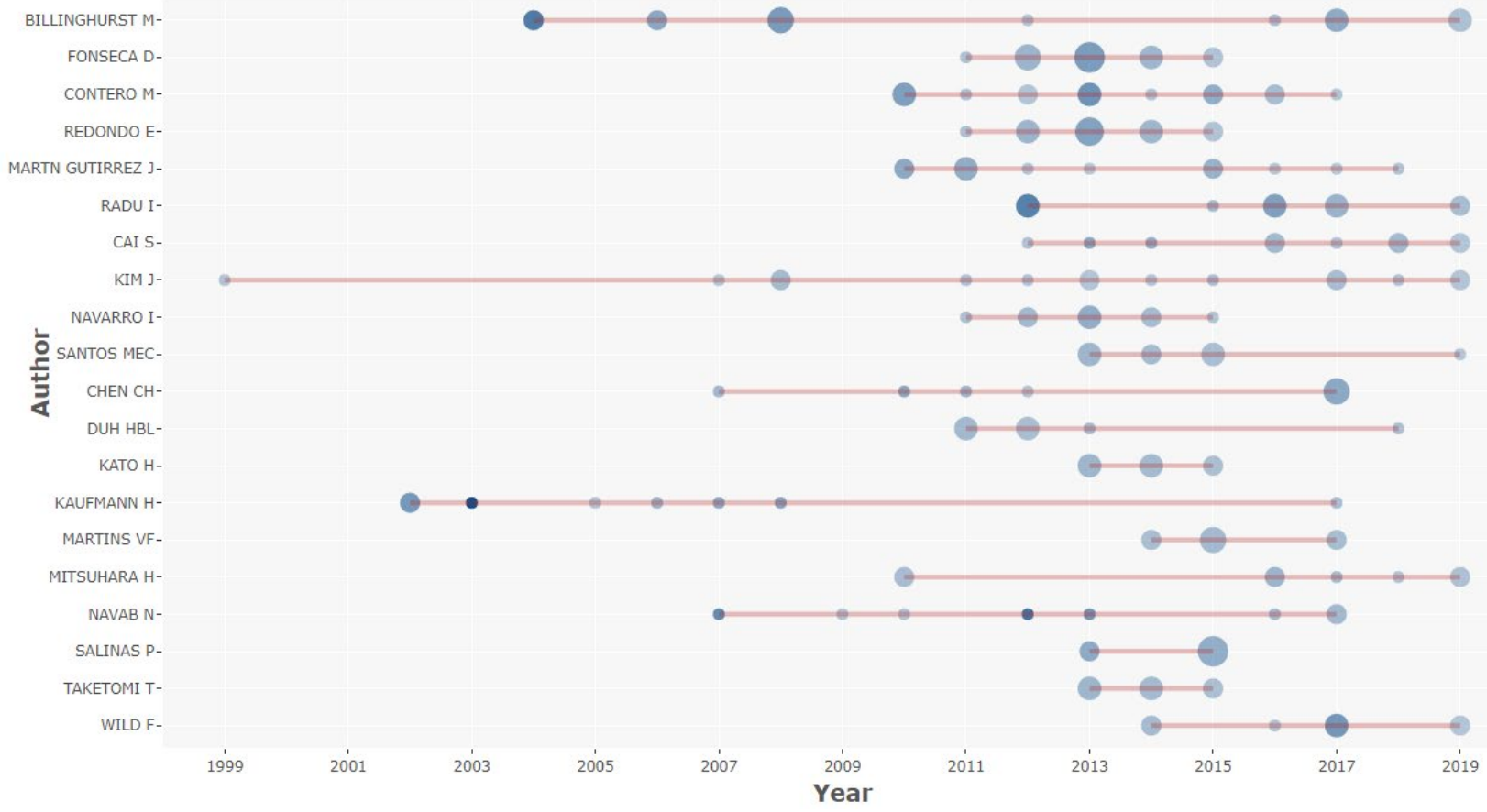

Figure 7. The top ten authors' production over time - Group B

Figures 8 and 9 show the number of authors that published AR studies over the examined years in the form of journal articles, conference papers, and other documents, respectively. The results for Groups $A$ and $B$ show that the number of researchers working on the topic of $A R$ in education increased every year. This result demonstrates the interest that this topic has created in the research community due to $A R$ technology's impact in education and the technological advances that make AR more affordable for schools. Given this landscape, it is possible that this trend will continue in the coming years and that this topic will be more consolidated in the future as the number of researchers increases. 


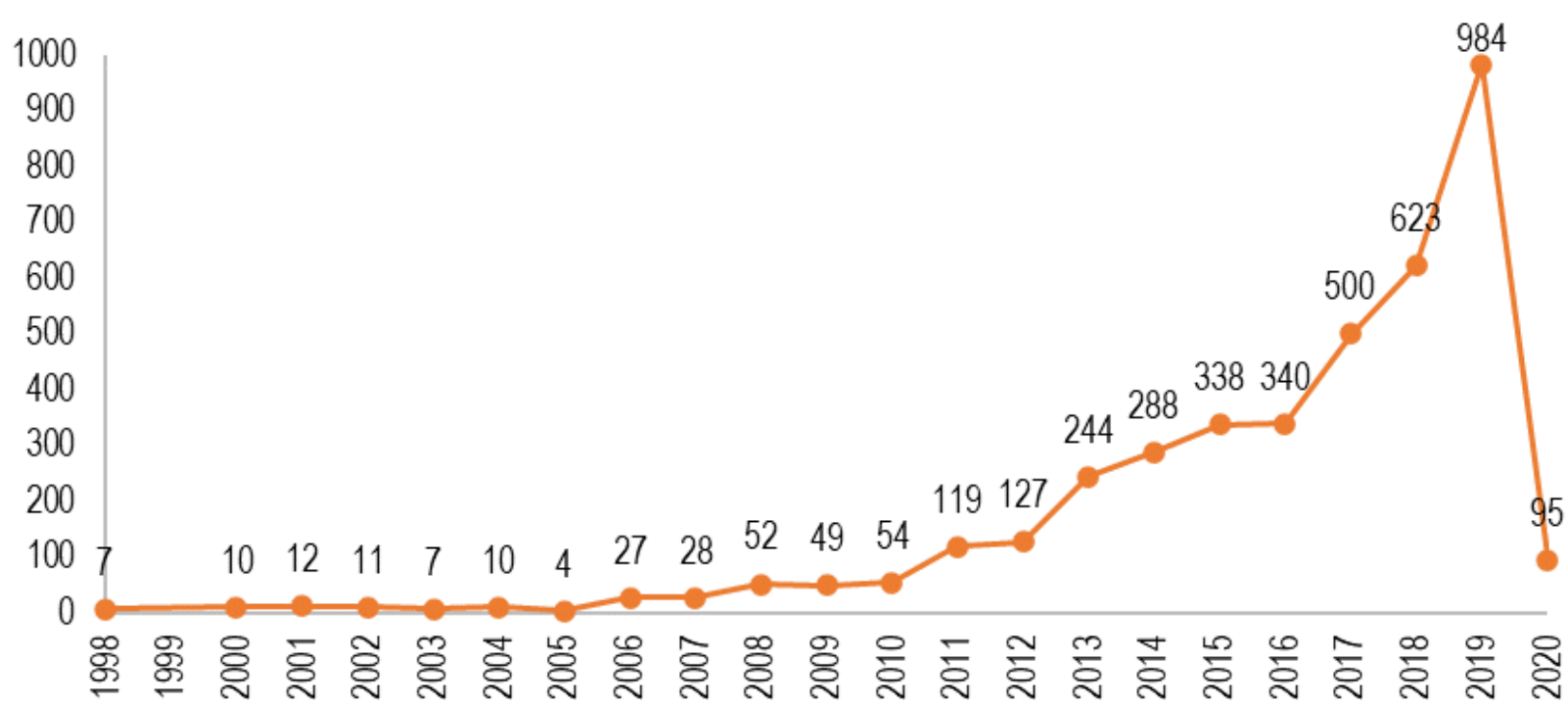

Figure 8. The number of authors that published AR studies over the years - Group $A$

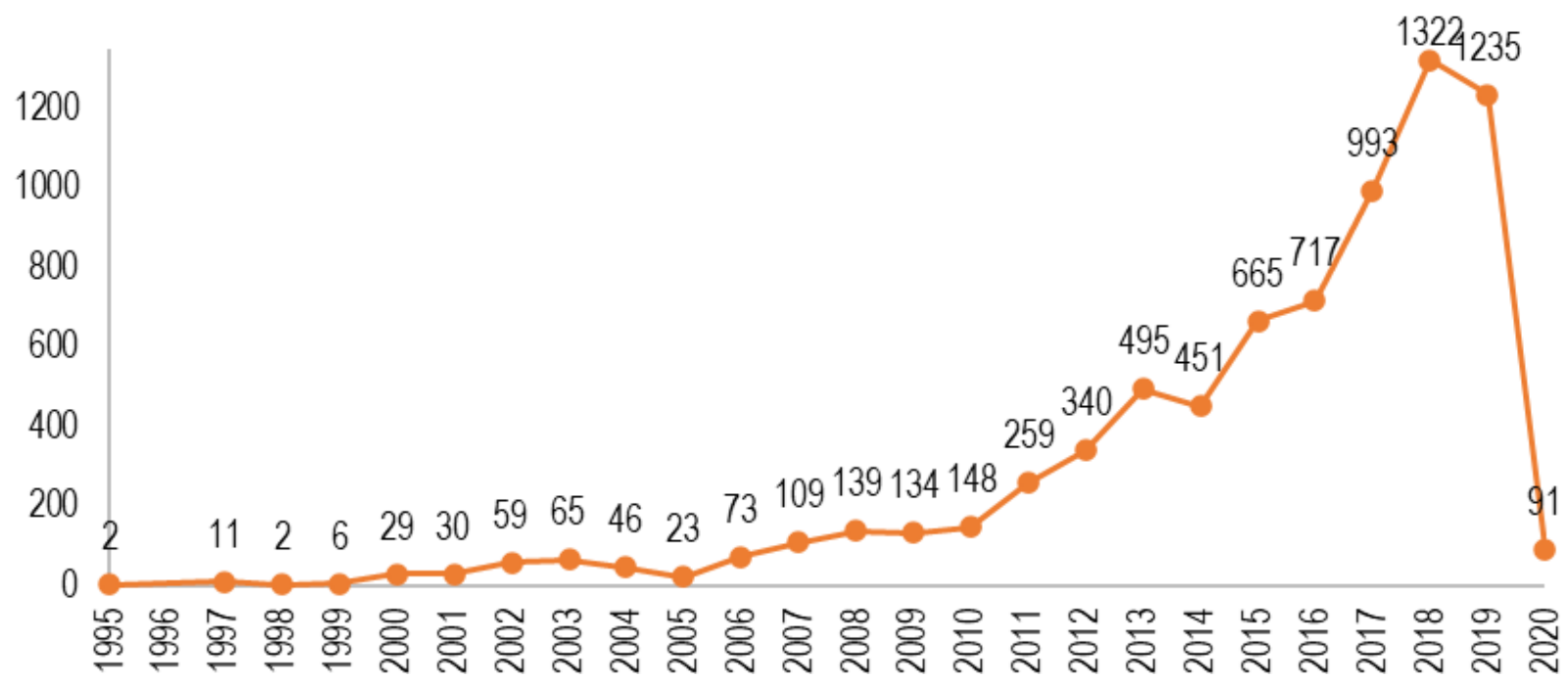

Figure 9. The number of authors that published AR studies over the years - Group B

\section{Which Keywords Do the Most Relevant Authors Use in Which Sources?}

Figure 10 presents a Sankey diagram depicting the most relevant authors in the field (on the left side of the figure), along with the main keywords (in the middle of the figure) they used in their publications and the most relevant sources (on the right side of the figure) in which these keywords appear for Group A (journal articles). The width of each line between an author, a keyword, and a journal source indicates the strength of the relationships between these aspects. The results show that the term 'augmented reality' is the most common keyword that has been used in journal articles. Other relevant keywords are 'virtual reality', 'interactive learning environments', 'mobile learning', 'education', 'ubiquitous learning', 'training', 'simulation', and 'laparoscopy'. These keywords often appear in the most relevant sources for this topic, namely Computers and Education, Interactive Learning Environments, and Computers in Human Behavior. This analysis might help other researchers identify the keywords that the most relevant authors have used the most frequently to increase the visibility of their articles and identify which authors are working on certain topics. The following keywords were used less often, but they might be related to emerging topics in this field: 'mobile augmented reality', 'game-based learning', 'gamification', and 'medical education'.

Figure 11 presents a Sankey diagram showing the keywords used by the most relevant authors in the most relevant sources for Group B (books, book chapters, and conference proceedings). In this case, the results are similar to those for journals. The most common term is 'augmented reality', followed by terms like 'virtual 


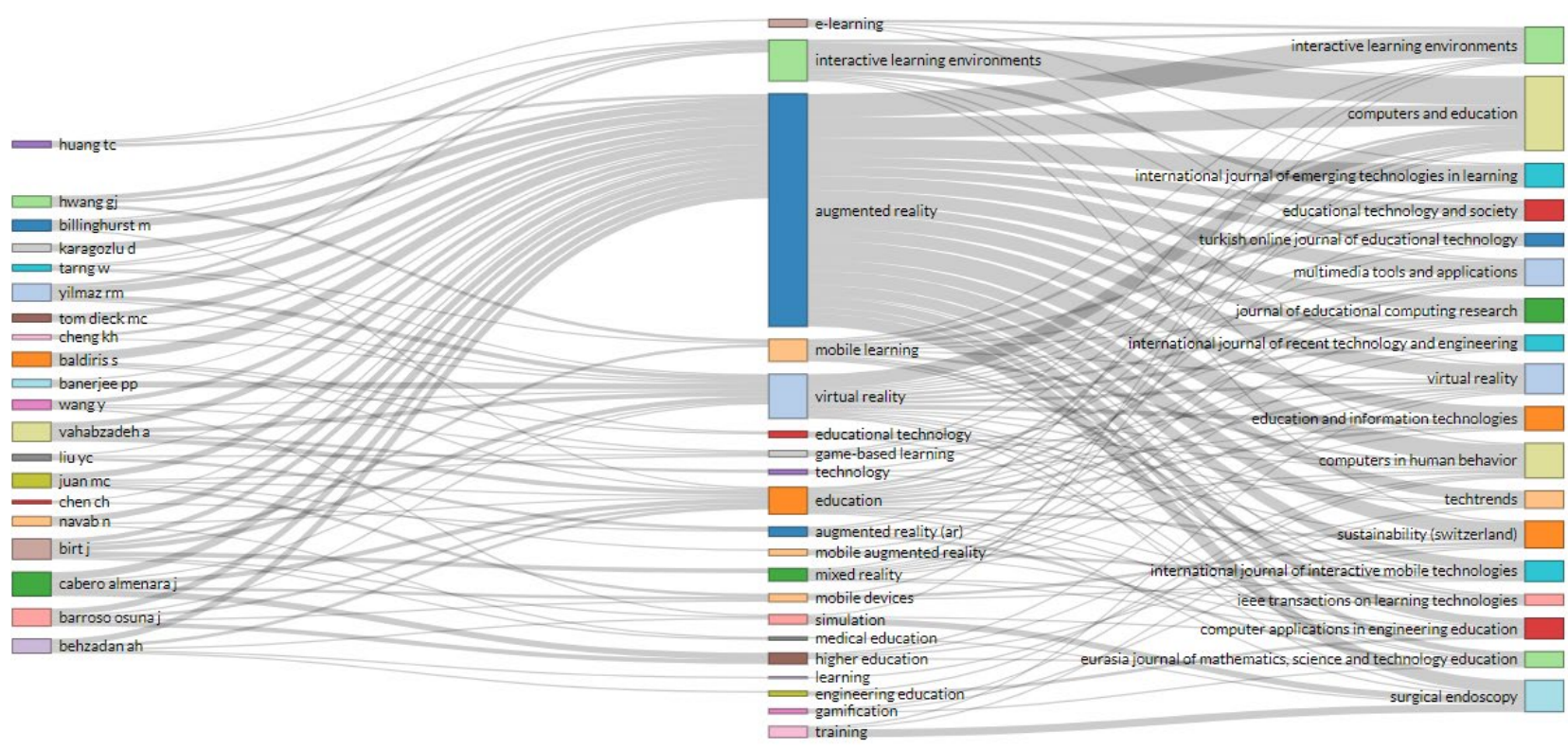

Figure 10. A Sankey diagram showing authors, keywords, and sources for Group A (journal articles)

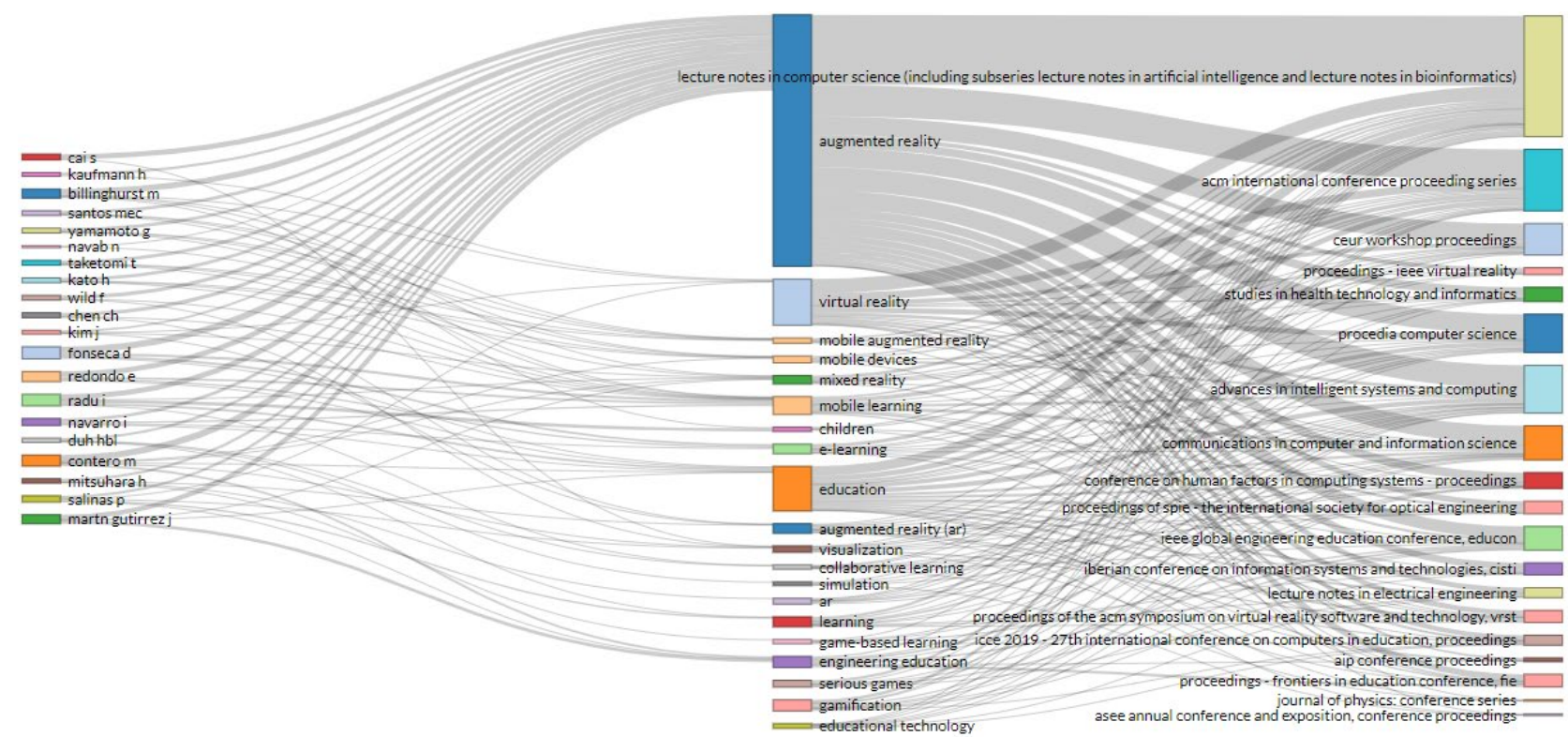

Figure 11. A Sankey diagram showing authors, keywords, and sources for Group B (books, book chapters, and proceedings)

reality', 'education', 'mobile learning', 'mobile devices', 'learning', 'engineering education', and 'mixed reality'. These terms often appear in conference proceedings published in Lecture Notes in Computer Science, ACM Proceedings Series, and Procedia Computer Science. Other terms that appear less frequently but might be related to emerging topics in the field include 'mobile augmented reality', 'children', 'cultural heritage', 'visualisation', 'simulation', 'serious games', 'gamification', 'game-based learning', and 'medical education'.

\section{The Co-Citation Network}

Figure 12 depicts the most cited studies in the field of AR in education. It is well known that Ronald Azuma (Azuma, 1997; Azuma et al., 2001) is one of the most cited authors in the field of AR. The Louvain algorithm, which allows for the extraction of communities from large networks and provides the most important vertices within the network using a centrality measure, was used to delineate the co-citation network. In this analysis, there are four clusters or communities. The top three most important authors and their centrality measures in each cluster are described as follows. In the first cluster, (Azuma et al., 2001) (78.72), (Azuma, 


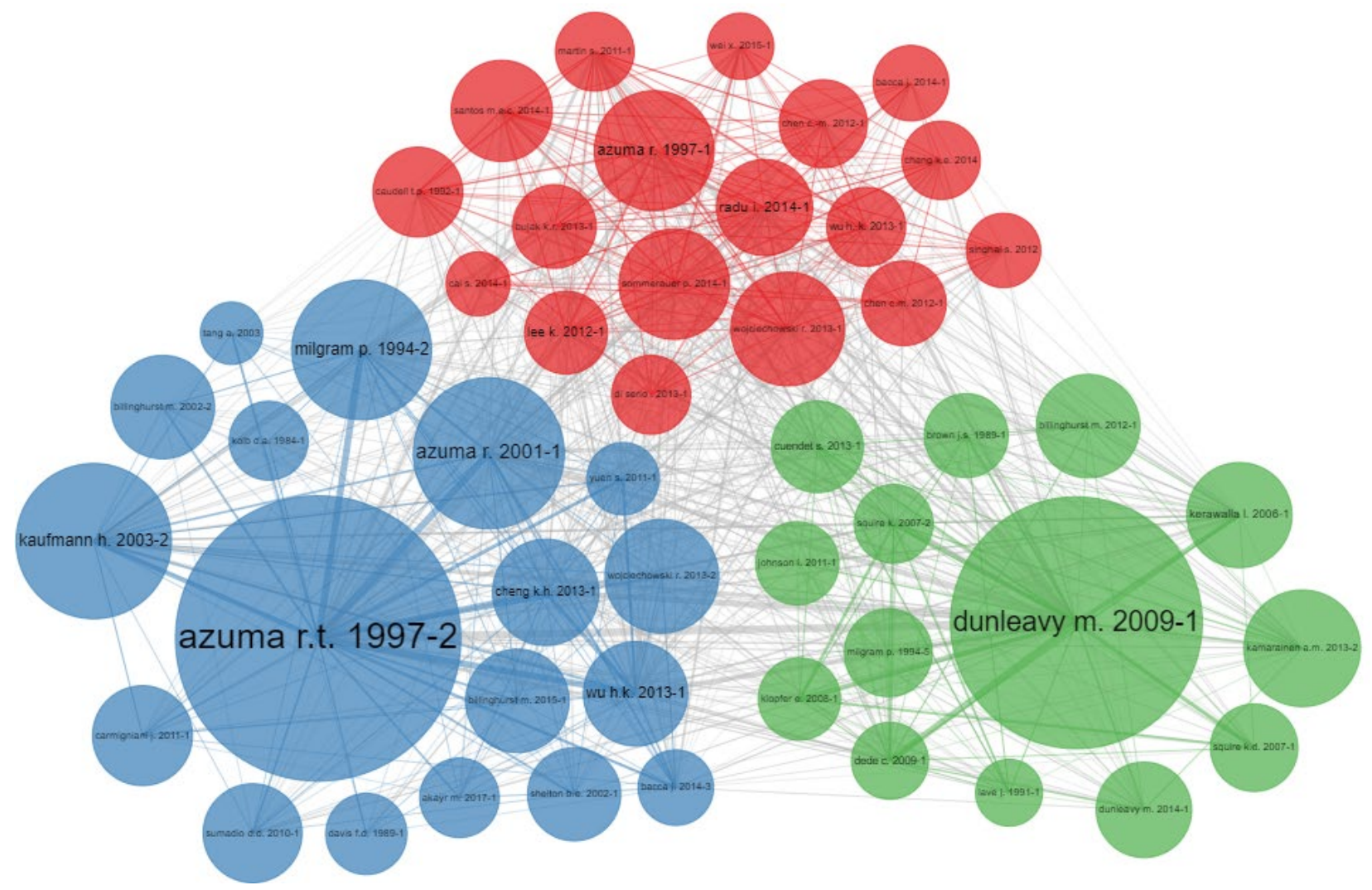

Figure 12. The co-citation network by papers - Group A

1997) (46.12), and (Kaufmann, 2003) (16.19). In the second cluster, (Azuma, 1997) (131.47), (Milgram et al., 1994) (58.48), and (Lee, 2012) (19.66). In the third cluster, (Dunleavy et al., 2009) (22.02), (Wu et al., 2013) (10.39), and (Squire \& Klopfer, 2007) (6.34). In the fourth cluster, (Feiner et al., 1993) (13.41), (Johnson et al., 2010) (10.52), and (Huang et al., 2016) (6.65).

The green and red clusters have the highest concentration of the most cited studies during the period 19972014, with Azuma and Dunleavy as the central nodes. In this co-citation network, Azuma (1997) and Dunleavy et al. (2009) are the central nodes in the co-citation network of papers from journals (Group A) and their studies can be considered seminal in the field of AR in education. The red cluster contains articles published from 2014 and later that became key articles in research on AR in education. This result might suggest that a new co-citation network is being created around these studies and that these studies might be defining new trends in research on AR in education. In the red cluster, the Radu's (2014), Wojciechowski and Cellary's (2013), and Sommerauer and Müller's (2014) studies are among the most cited in the field of AR in education.

In Group B (conference papers, books, and book chapters), the landscape is similar (see Figure 13). Azuma's and Dunleavy's articles are the most cited in the field. However, a new cluster appears (blue cluster), with authors like Yilmaz (2016), and Huang et al. (2016).

\section{CONTENT ANALYSIS}

\section{Word Cloud}

Creating a word cloud is a strategy for analysing the frequency at which certain words appear in a text. Figure 14 shows the word cloud for each group according to each year's relevant topics. The cloud includes 50 words that appear frequently in abstracts across all papers. The most frequently used words and phrases were 'learning', 'augmented reality', 'students', 'education', and 'technology'. The dark colours represent the relevant topics in 2016, and the lightest colour represents relevant topics in 2016 onwards. Table 3 presents some extracts from Figure 14 with the emerging and trending topics in the field from 2018 onwards. 


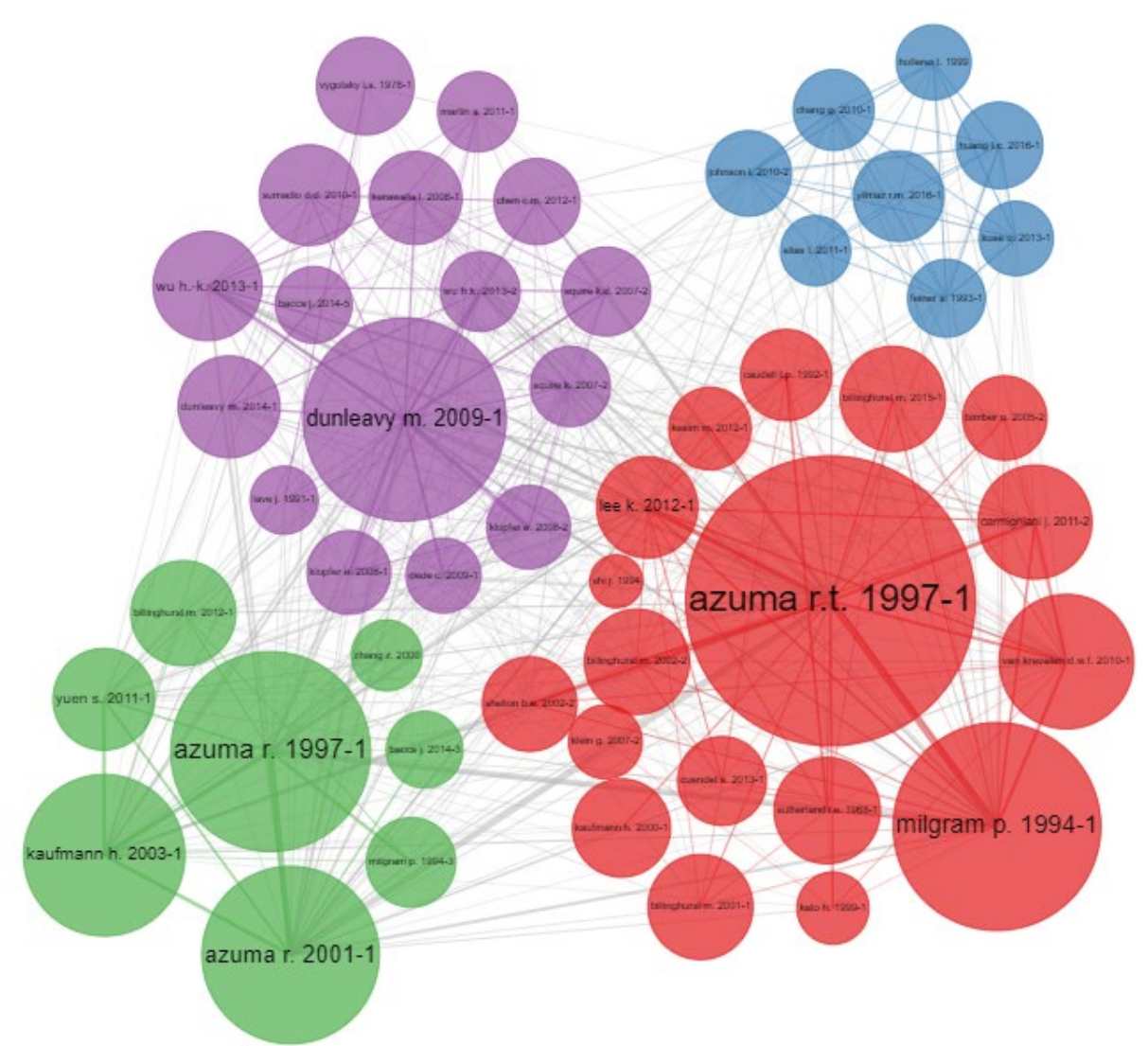

Figure 13. The co-citation network by papers - Group B

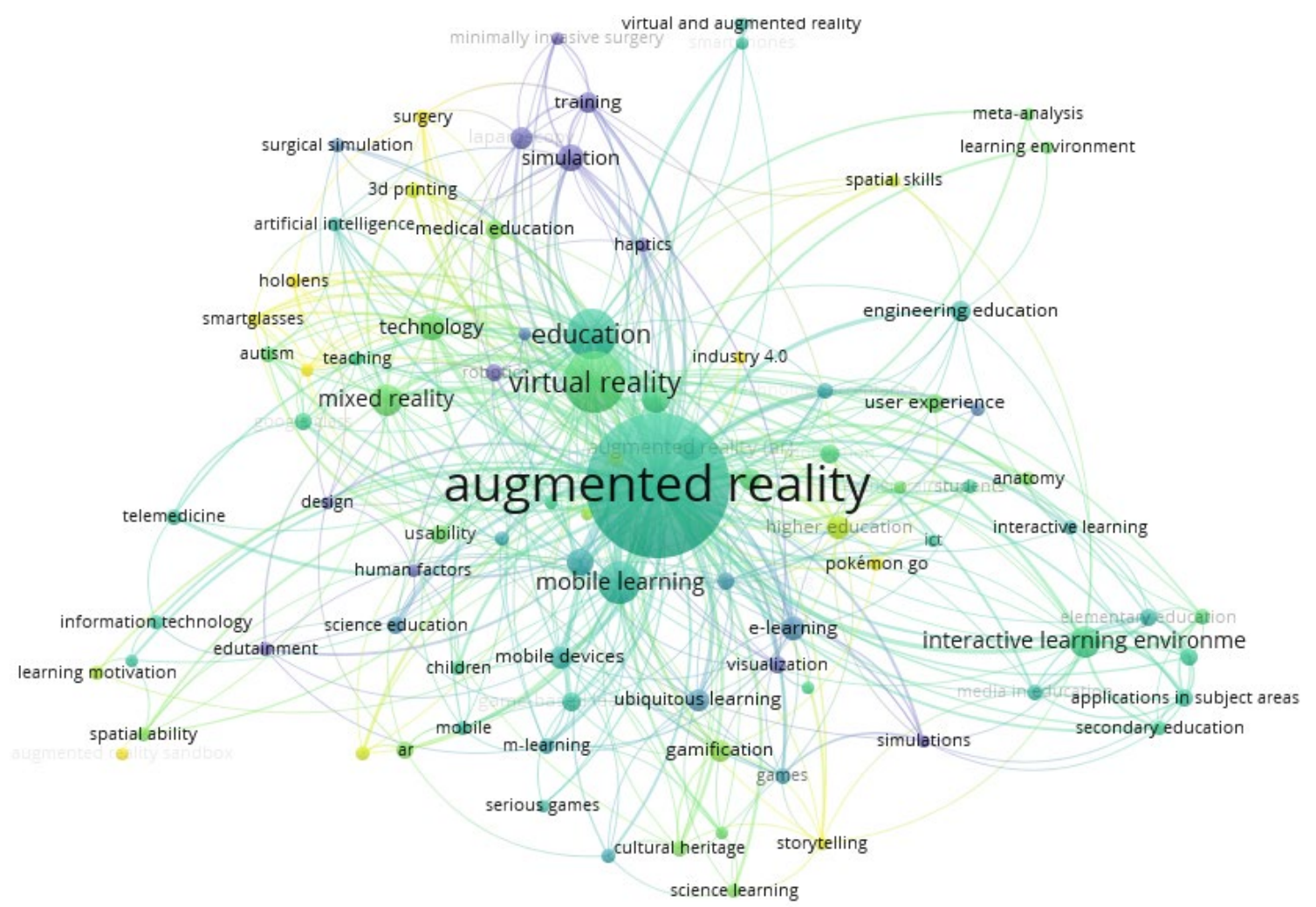

science learning

Figure 14. Analysis of words 
Table 3. Current emerging and trending topics from 2018 onwards

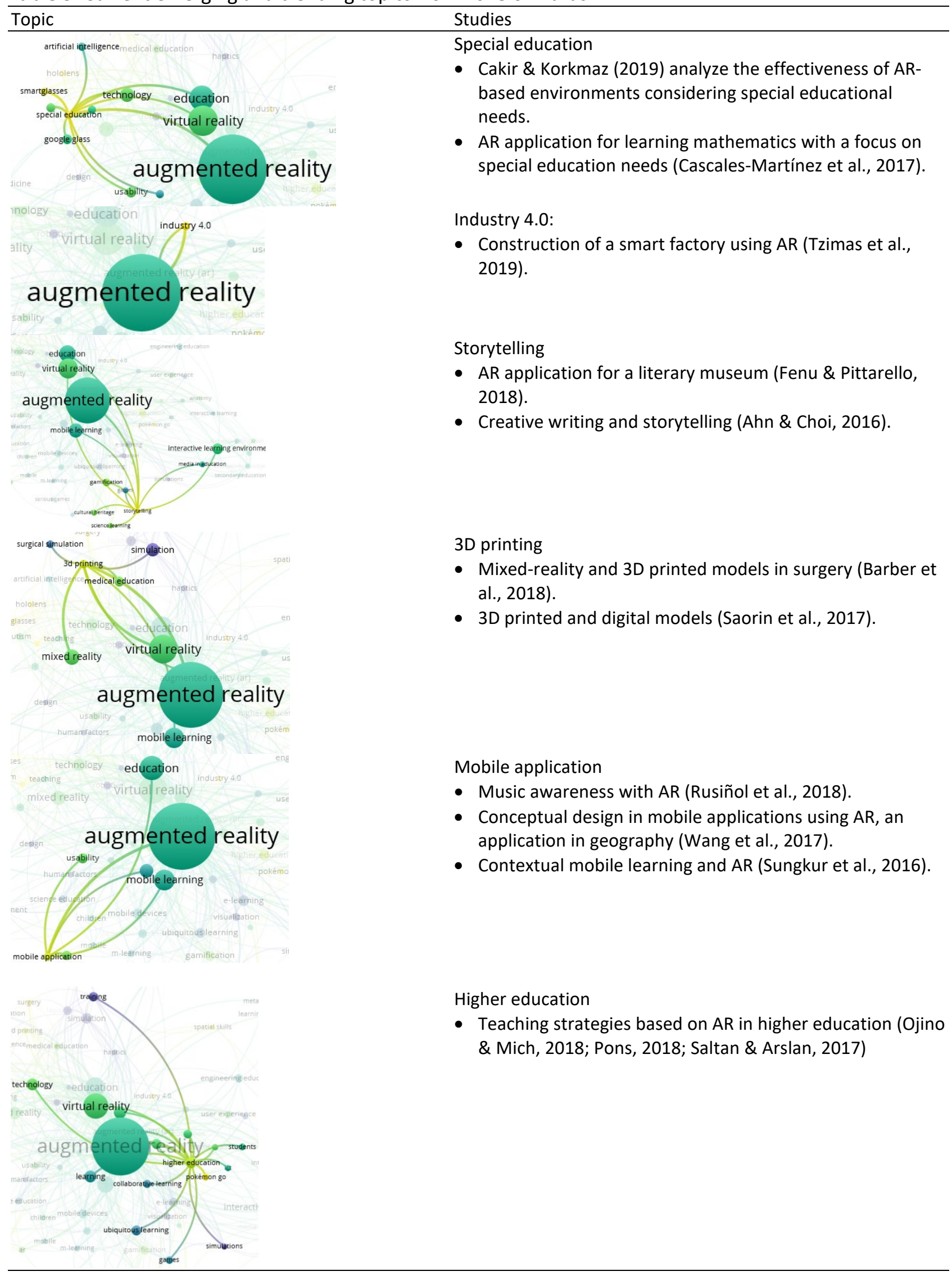




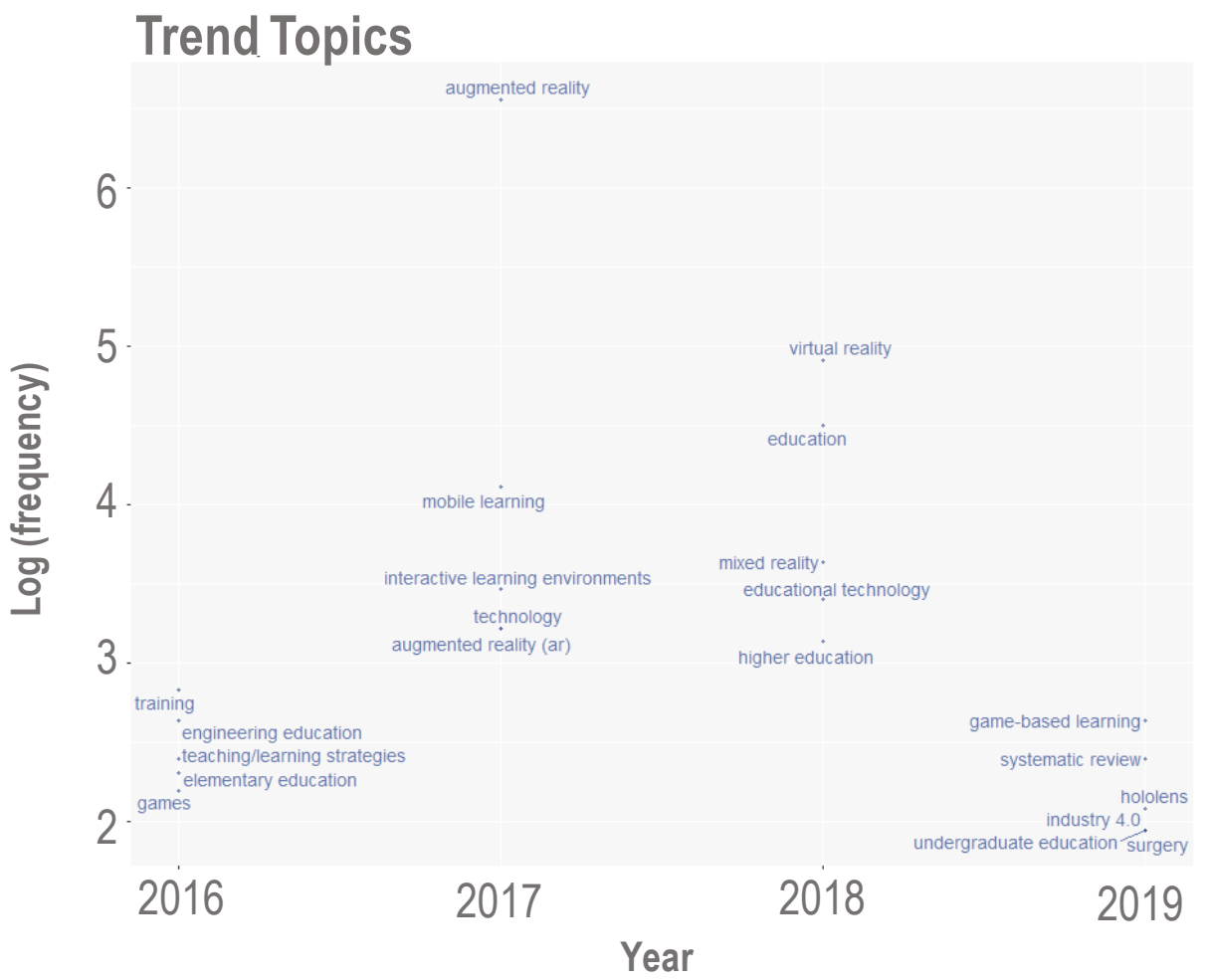

Figure 15. The top five authors' keywords for Group A by year from 2016 to 2019

\section{Analysis of Keywords}

This analysis was conducted using authors' keywords for each study published between 2016 and 2019 in journal articles. To obtain the most frequently used keywords, we only considered keywords that appeared more than five times in all of the journal articles, and we only reported the top five keywords in each year. Figure 15 shows the top five keywords in order of frequency for every year from 2016 to 2019 in journal articles. The results show that, in order of frequency, in 2018, the most relevant keywords in the articles were 'virtual reality', 'education', 'mixed reality', 'educational technology', and 'higher education'. These keywords show a strong relationship between AR, VR, and mixed reality as immersive learning technologies. Moreover, the results point to increasing interest in research on the use VR in educational settings, as this technology is becoming more affordable for some educational institutions. The keywords 'education' and 'educational technology' are general terms that always appear in connection with AR. It is worth noting that the keyword 'higher education' was also among the most frequently used keywords in 2018.

For 2019, the top five keywords were 'game-based learning', 'HoloLens', 'Industry 4.0', 'undergraduate education', and 'surgery'. The most common keyword was 'game-based learning', which shows that a large number of journal articles focused on how game-based learning strategies can be combined with AR learning experiences. This combination often appears in the literature as AR game-based learning (ARGBL) (Pellas et al., 2019; Tobar-Muñoz et al., 2017). In 2019, the keyword 'HoloLens' appeared again, showing that interest in this device continues to grow in the research community. A possible interpretation of this result might be that researchers are investigating the possibilities, benefits, and limitations of this device for the development of AR learning experiences. Overall, there might be general interest in investigating the impact of AR in education with different devices. In 2019, the keyword 'undergraduate education' also pointed to a similar interest observed in 2018 at the higher education level. This result shows that a large number of studies with AR have been conducted in higher education, as access to this population might be easier for some researchers. Other keywords that became relevant in 2019 were 'Industry 4.0' and 'surgery'. The former is as a relevant keyword because AR is considered to be part of the new industrial revolution (Masood \& Egger, 2019), and researchers are currently investigating the possibilities of this technology in educational 


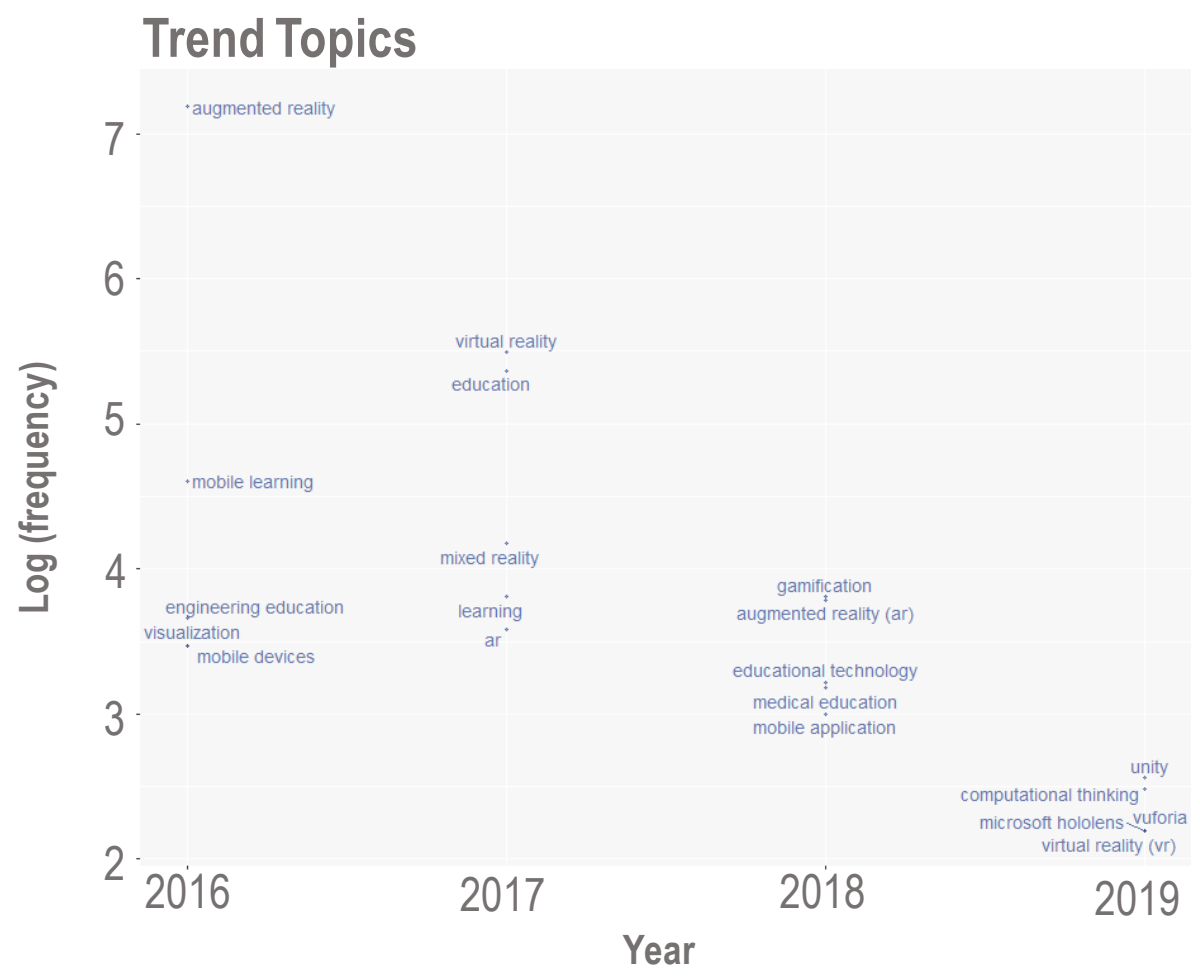

Figure 16. The top five authors' keywords for Group B by year from 2016 to 2019

settings for new industries. Finally, the keyword 'surgery' refers to increasing interest in using AR in medical education.

Figure 16 shows the top five keywords that appeared in book chapters and conference papers from 2016 to 2019. In 2018, the top five keywords were 'gamification', 'augmented reality', 'educational technology', 'medical education', and 'mobile application'. The results show that gamification is important in research on $A R$ in education. The results of this analysis, combined with the analysis of journal articles, show that gamification and game-based learning might be hot topics in research on AR in education. The keywords 'augmented reality' and 'educational technology' are common in the field. However, the keyword 'medical education' confirms the fact that in journal articles, book chapters, and conference papers, there is increasing interest in investigating the affordances of AR in medical education. Finally, the keyword 'mobile application' suggests that the popularity of mobile devices, their affordability, and technological advances in this field have favoured the development of more mobile AR applications, and researchers are using mobile AR as a medium to evaluate the effect of AR in education.

For 2019, the results presented in Figure 16 show that the top five keywords were 'Unity', 'computational thinking', 'virtual reality', 'Microsoft HoloLens', and 'Vuforia'. The keywords used within this period reflect that research has focused on how some technologies, such as the Microsoft HoloLens and software platforms such as Unity and Vuforia, might be used to develop AR learning experiences. In these results, the keyword 'Unity' refers to one of the most common software platforms currently used for the development of AR learning experiences. This term often appears in the literature together with the 'Vuforia' software because Vuforia is commonly used in conjunction with Unity for the development of AR-based applications. The results also show that the term 'virtual reality' appeared again in 2019 as a relevant keyword, confirming researchers' interest in the use of VR in educational settings. Finally, the keyword 'computational thinking' might suggest that some research is being conducted to determine how immersive technologies can be used to foster programming skills (Cepeda \& Bacca, 2019). 


\section{DISCUSSION}

\section{RQ1: How Has AR in Education Evolved in Terms of Annual Scientific Growth, The Countries That Contribute the Most, and the Most Relevant Publication Sources?}

The results of the bibliometric study show that the annual growth rate of publications in journals and conferences on the topic of AR in education is approximately $21 \%$. This result suggests that not only has there been continuous interest in this topic, the number of related articles is increasing, thus confirming the findings of Akçayır and Akçayır (2017), Herpich et al. (2019), and López et al. (2019) regarding the increase in the number of publications in the field of AR in education. It is important to note that 2011 is the year in which the number of publications in AR in education sky-rocketed and then rose steadily year after year. This result might suggest that the field's research communities are consolidating more and more research as the field gains momentum and that we are close to the point at which this technology might mature and be widely adopted in the educational sector.

As for the country scientific production, the results show that the USA, Spain and Taiwan are the three most contributing countries for both types of publications: conference papers and journal articles. These three countries are also the countries with a long tradition of research in the field with publications prior to 2014. This result is consistent with the findings by López et al. (2019), and Karakus et al. (2019) in terms of the country scientific production of research on AR in education. Moreover, we also identified that Mexico, Malaysia, India, Indonesia and Colombia are some of the countries that are starting to contribute to the field more recently.

The results show that the most relevant journals that have published research on $A R$ in education are Computers and Education, Interactive Learning Environments, and Computers in Human Behavior. This result is similar to those Arici et al. (2019) reported in the field of AR in science education.

\section{RQ2: Who Are the Authors That Have Contributed the Most to AR in Education as Measured by the Number of Publications and Citations per Year?}

Although Azuma is one of the most cited authors in the field, among the top ten authors that have contributed the most, Hwang is the most cited in journal articles, and Billinghurst is the most cited in conference papers and book chapters. It is important to note that this result considers the top ten most cited authors with respect to the number of publications per year and the number of citations of those publications.

The co-citation network that was delineated based on this bibliometric analysis provides an overview of research on AR in education that has been published in journal articles as well as in conference papers and book chapters. In the co-citation network, Azuma and Dunleavy are among the most cited authors in the field. This result is in line with the findings of Cipresso et al. (2018), who noted that Azuma's articles are the most cited in the field of AR in education. These results are also in line with the co-citation network that was created based on the results of Arici et al.'s (2019) bibliometric analysis in the field of science education. Moreover, the clusters in this study's co-citation network (see Figures 12 and 13) show the most cited articles and authors in the field of AR in education over the past 25 years.

By analysing the co-citation clusters for journal articles (Group A - see Figure 12), it was found that Azuma and Dunleavy authored the most-cited studies in the field. However, after 2014, a new group of journal articles, including studies by Radu (2014), Wojciechowski and Cellary (2013), and Sommerauer and Müller (2014), created a new cluster of co-citations, possibly defining new trends in research on AR in education. These results might suggest that Azuma's and Dunleavy's articles marked the first generation of research on AR in education, but from 2014 onwards, a second generation was born. A possible interpretation of this result might be that the more recent articles cited the most recent studies, and for that reason, a new cocitation cluster was created after 2014. This finding is also consistent with that of López et al. (2019), who found that the period from 2015 to the present has been the most productive period for research on AR in higher education. 
The co-citation network for papers in Group B (conference papers, books, and book chapters) yielded results that are similar to those obtained for journal articles. However, one more cluster appears in the co-citation network: the blue cluster. In this cluster, the central nodes are Yilmaz's (2016), and Huang et al.'s (2016) studies. This cluster of articles might represent a new generation of research on AR in education.

\section{RQ3: What Are the Future Research Directions in AR in Education?}

The trending topics in AR in education that were identified as part of this bibliometric analysis are as follows:

- The use of AR in learning environments populated by students with special educational needs

- Using AR as part of the Industry 4.0 movement

- The support that AR provides for educational activities that involve storytelling

- The combination of 3D printing and mixed reality for learning purposes

- Investigating the use of mobile devices for deploying AR learning experiences

- Increasing interest in exploring the effect of AR in higher education courses

From the analysis of the authors' keywords, we identified the most frequent keywords in the articles. These keywords might provide insights into topics in AR in education due to their prevalence in journals, book chapters, and conference papers. The results show that gamification and game-based learning are keywords that frequently appear in articles from journals, book chapters, and conference papers. This result might suggest increasing interest in applying gamification strategies and the theory of game-based learning to the development of AR learning experiences. This result confirms previous findings in systematic literature reviews in the field of AR game-based learning (Koutromanos et al., 2015; Laine, 2018; Li et al., 2017; Pellas et al., 2019) and reinforces the findings of Karakus et al.'s (2019) bibliometric analysis. Other keywords that appeared frequently were 'medical education' and 'surgery'. This result suggests increasing interest in the use of AR for medical education because of the new opportunities that AR is creating for the visualisation and simulation of medical procedures. This result is in line with previous findings in systematic literature reviews in the field of AR in medical education (Barsom et al., 2016; Joda et al., 2019; McCarthy \& Uppot, 2019; Sen et al., 2018).

The results also show that there is increasing interest in investigating the use of AR in higher education settings, which has been previously noted by López et al. (2019). This result also confirms previous findings by Garzón et al. (2019), who noted that higher education and primary education are two of the educational levels for which more AR research has been conducted.

One of the topics that did not appear among the trending topics is the development of authoring tools that enable teachers to create content for AR learning experiences or modify existing content to add new functionalities. This issue is often reported in the literature (Fidan \& Tuncel, 2019). Another topic that is starting to appear as a remarkable concern is that public schools should provide the technologies needed to deploy AR learning experiences, so that all students can have the same experience, given that there are some students that might not have access to some technologies (Fidan \& Tuncel, 2019).

\section{CONCLUSION}

This paper reports the results of a bibliometric analysis of 25 years (1995-2020) of research on AR in education. From 3,475 papers, we identified annual scientific growth, the authors that contributed the most, the outcomes of the co-citation analysis, scientific production over time, and trending topics. By analysing these results, we observed a wide variety of aspects that influence growth and evolution in this field.

The number of publications on AR in education is increasing, and the field is gaining momentum. Regarding countries' scientific production, the United States, Spain, and Taiwan are the three leading countries in the publication of research on AR in education. In terms of journal sources, Computers and Education, Interactive 
Learning Environments, and Computers in Human Behavior are among the most important journals for publishing research on AR in education. Most conference papers are published in the lecture notes in Computer Science because some of the conferences publish their proceedings under this series.

Although Azuma is one of the most cited authors in the field, when we analysed the contributions per year and the number of citations, Hwang was found to be both the most prolific and the most cited author among the top ten authors in the field. For conference papers, books, and book chapters, Billinghurst is the most prolific and the most cited author among the top ten contributors. The co-citation network shows that Azuma and Dunleavy authored the most-cited studies in the field of AR in education. However, from 2014 onwards, a new cluster of highly-cited journal articles appeared as a new generation of research in the field of AR in education. The case for conference papers, books, and book chapters is similar, but the new cluster appeared around 2016.

The current emerging and trending research topics in AR in education are special educational needs, Industry 4.0, storytelling, 3D printing, mobile applications, and higher education. These results were confirmed by the results of the analysis of authors' keywords, from which the concepts of 'gamification' and 'game-based learning' were also identified as important in research on AR in education. There is also increasing interest in designing AR learning experiences for higher education. The keywords also show that some recent studies have focused on investigating how AR can be used in medical education.

Author contributions: All authors were involved in concept, design, collection of data, interpretation, writing, and critically revising the article. All authors approve final version of the article.

Funding: The authors received no financial support for the research and/or authorship of this article.

Declaration of interest: Authors declare no competing interest.

Data availability: Data generated or analysed during this study are available from the authors on request.

\section{REFERENCES}

Abad-Segura, E., González-Zamar, M.-D., Luque-de la Rosa, A., \& Morales, M. (2020). Sustainability of Educational Technologies: An Approach to Augmented Reality Research. Sustainability, 12(10), 4091. https://doi.org/10.3390/su12104091

Ahn, H.-S., \& Choi, Y.-M. (2016). Utilizing augmented reality for creative writing educational contents and story-retelling. International Journal of Multimedia and Ubiquitous Engineering, 11(12), 71-82. https://doi.org/10.14257/ijmue.2016.11.12.07

Akçayır, M., \& Akçayır, G. (2017). Advantages and challenges associated with augmented reality for education: A systematic review of the literature. Educational Research Review, 20, 1-11. https://doi.org/10.1016/j.edurev.2016.11.002

Aria, M., \& Cuccurullo, C. (2017). Bibliometrix: An R-tool for comprehensive science mapping analysis. Journal of Informetrics, 11(4), 959-975. https://doi.org/10.1016/j.joi.2017.08.007

Arici, F., Yildirim, P., Caliklar, Ş., \& Yilmaz, R. M. (2019). Research trends in the use of augmented reality in science education: Content and bibliometric mapping analysis. Computers \& Education, 142, 103647. https://doi.org/10.1016/j.compedu.2019.103647

Azuma, R. (1997). A Survey of Augmented Reality. Presence: Teleoper. Virtual Environ., 6(4), 355-385. https://doi.org/10.1162/pres.1997.6.4.355

Azuma, R. (2001). Augmented Reality: Approaches and Technical Challenges. En Fundamentals of Wearable Computers and Augmented Reality (1. ${ }^{a}$ ed.). CRC Press. https://doi.org/10.1201/9780585383590-7

Azuma, R., Baillot, Y., Behringer, R., Feiner, S., Julier, S., \& Maclntyre, B. (2001). Recent advances in augmented reality. IEEE Computer Graphics and Applications, 21(6), 34-47. https://doi.org/10.1109/38.963459 
Bacca, J., Baldiris, S., Fabregat, R., \& Kinshuk. (2018). Insights into the factors influencing student motivation in Augmented Reality learning experiences in Vocational Education and Training. Frontiers in Psychology, 9(AUG). https://doi.org/10.3389/fpsyg.2018.01486

Barber, S. R., Jain, S., Son, Y.-J., \& Chang, E. H. (2018). Virtual Functional Endoscopic Sinus Surgery Simulation with 3D-Printed Models for Mixed-Reality Nasal Endoscopy. Otolaryngology - Head and Neck Surgery (United States), 159(5), 933-937. https://doi.org/10.1177/0194599818797586

Barsom, E., Graafland, M., \& Schijven, M. (2016). Systematic review on the effectiveness of augmented reality applications in medical training. Surgical Endoscopy, 30(10), 4174-4183. https://doi.org/10.1007/s00464-016-4800-6

Bernal, J., Bacca, J., \& Daza, J. (2019). Una aplicación móvil de Realidad Aumentada para la enseñanza de la gestión de almacenes en logística [An Augmented Reality mobile application for teaching warehouse management in logistics]. In Desarrollo e Innovación en Ingeniería (4th Ed., pp. 85-95). Editorial Instituto Antioqueño de Investigación. https://doi.org/10.5281/zenodo.3387679

Bhagat, K. (2019). Augmented reality research output from 1990-2018: A bibliometric analysis. Proceedings of the 27th International Conference on Computers in Education, 2, 61-65. http://ilt.nutn.edu.tw/icce2019/dw/ICCE2019\%20Proceedings\%20Volume\%20II.pdf

Bornmann, L., \& Leydesdorff, L. (2014). Scientometrics in a changing research landscape: Bibliometrics has become an integral part of research quality evaluation and has been changing the practice of research. EMBO Reports, 15(12), 1228-1232. https://doi.org/10.15252/embr.201439608

Brown, M., McCormack, M., Reeves, J., Brooks, C., Alexander, B., Grajek, S., Bali, M., \& Bulger, S. (2020). 2020 EDUCAUSE Horizon Report / Teaching and Learning Edition (p. 58). EDUCAUSE. https://library.educause.edu/-/media/files/library/2020/3/2020_horizon_report_pdf.pdf?la=en\& hash=08A92C17998E8113BCB15DCA7BA1F467F303BA80

Cakir, R., \& Korkmaz, O. (2019). The effectiveness of augmented reality environments on individuals with special education needs. Education and Information Technologies, 24(2), 1631-1659. https://doi.org/10.1007/s10639-018-9848-6

Calabuig-Moreno, F., González-Serrano, M. H., Fombona, J., \& García-Tascón, M. (2020). The Emergence of Technology in Physical Education: A General Bibliometric Analysis with a Focus on Virtual and Augmented Reality. Sustainability, 12(7), 2728. https://doi.org/10.3390/su12072728

Cano, B., Hernández, J., \& Bacca, J. (2019). Aplicación móvil con realidad aumentada para practicar las preposiciones de lugar en inglés: Estudio de usabilidad y aceptación [Mobile application with augmented reality to practice prepositions of place in English: Study of usability and acceptance]. In Investigación Formativa en Ingeniería (3rd Ed., pp. 22-31). Instituto Antioqueño de Investigación. http://doi.org/10.5281/3387691

Cascales-Martínez, A., Martínez-Segura, M.-J., Pérez-López, D., \& Contero, M. (2017). Using an augmented reality enhanced tabletop system to promote learning of mathematics: A case study with students with special educational needs. Eurasia Journal of Mathematics, Science and Technology Education, 13(2), 355-380. https://doi.org/10.12973/eurasia.2017.00621a

Cepeda, D., \& Bacca, J. (2019). Aplicación móvil para la enseñanza de la programación sobre el lenguaje Python [Mobile application for teaching programming on the Python language]. In Revolución en la Formación y la Capacitación para el Siglo XXI (2nd Ed., Vol. 2, pp. 925-933). Editorial Instituto Antioqueño de Investigación. http://doi.org/10.5281/zenodo.3524363

Charalampos, N. (2020). BibTooL: a suite of tools for simple operations on BibTeX files. BibTooL: a suite of tools for simple operations on BibTeX files. http://cgi.di.uoa.gr/ charnik/oss/bibtool/\#lic 
Chiang, T. H. C., Yang, S. J. H., \& Hwang, G.-J. (2014). An Augmented Reality-based Mobile Learning System to Improve Students' Learning Achievements and Motivations in Natural Science Inquiry Activities. Journal of Educational Technology \& Society, 17(4), 352-365.

Cipresso, P., Chicchi Giglioli, I. A., Alcaniz Raya, M., \& Riva, G. (2018). The Past, Present, and Future of Virtual and Augmented Reality Research: A Network and Cluster Analysis of the Literature. Frontiers in Psychology, 9, 2086. https://doi.org/10.3389/fpsyg.2018.02086

Dunleavy, M., Dede, C., \& Mitchell, R. (2009). Affordances and Limitations of Immersive Participatory Augmented Reality Simulations for Teaching and Learning. Journal of Science Education and Technology, 18(1), 7-22. https://doi.org/10.1007/s10956-008-9119-1

Ellegaard, O., \& Wallin, J. A. (2015). The bibliometric analysis of scholarly production: How great is the impact? Scientometrics, 105(3), 1809-1831. https://doi.org/10.1007/s11192-015-1645-z

Feiner, S., Macintyre, B., \& Seligmann, D. (1993). Knowledge-based Augmented Reality. Communications of the ACM, 36(7), 53-62. https://doi.org/10.1145/159544.159587

Fellnhofer, K. (2019). Toward a taxonomy of entrepreneurship education research literature: A bibliometric mapping and visualization. Educational Research Review, 27, 28-55. https://doi.org/10.1016/j.edurev.2018.10.002

Fenu, C., \& Pittarello, F. (2018). Svevo tour: The design and the experimentation of an augmented reality application for engaging visitors of a literary museum. International Journal of Human Computer Studies, 114, 20-35. https://doi.org/10.1016/j.ijhcs.2018.01.009

Fidan, M., \& Tuncel, M. (2019). Integrating augmented reality into problem based learning: The effects on learning achievement and attitude in physics education. Computers \& Education, 142, 103635. https://doi.org/10.1016/j.compedu.2019.103635

Garzón, J., Pavón, J., \& Baldiris, S. (2019). Systematic review and meta-analysis of augmented reality in educational settings. Virtual Reality. https://doi.org/10.1007/s10055-019-00379-9

Garzón, Juan, \& Acevedo, J. (2019). Meta-analysis of the impact of Augmented Reality on students' learning gains. Educational Research Review, 27, 244-260. https://doi.org/10.1016/j.edurev.2019.04.001

Garzón, Juan, Kinshuk, Baldiris, S., Gutiérrez, J., \& Pavón, J. (2020). How do pedagogical approaches affect the impact of augmented reality on education? A meta-analysis and research synthesis. Educational Research Review, 31, 100334. https://doi.org/10.1016/j.edurev.2020.100334

Herpich, F., Nunes, F., Petri, G., \& Tarouco, L. (2019). How Mobile Augmented Reality Is Applied in Education? A Systematic Literature Review. Creative Education, 10(7), 1589-1627. https://doi.org/10.4236/ce.2019.107115

Huang, T.-C., Chen, C.-C., \& Chou, Y.-W. (2016). Animating eco-education: To see, feel, and discover in an augmented reality-based experiential learning environment. Computers \& Education, 96, 72-82. https://doi.org/10.1016/j.compedu.2016.02.008

Ibañez, M., Uriarte, A., Zatarain, R., \& Barrón, M. (2020). Impact of augmented reality technology on academic achievement and motivation of students from public and private Mexican schools. A case study in a middle-school geometry course. Computers \& Education, 145, 103734. https://doi.org/10.1016/j.compedu.2019.103734

Joda, T., Gallucci, G., Wismeijer, D., \& Zitzmann, N. (2019). Augmented and virtual reality in dental medicine: A systematic review. Computers in Biology and Medicine, 108, 93-100. https://doi.org/10.1016/j.compbiomed.2019.03.012 
Johnson, L., Levine, A., Smith, R., \& Stone, S. (2010). Simple augmented reality. The 2010 Horizon Report, 2124.

Karakus, M., Ersozlu, A., \& Clark, A. C. (2019). Augmented Reality Research in Education: A Bibliometric Study. Eurasia Journal of Mathematics, Science and Technology Education, 15(10), em1755. https://doi.org/10.29333/ejmste/103904

Kaufmann, H. (2003, marzo 20). Collaborative Augmented Reality in Education. Imagina Conference 2003. https://www.ims.tuwien.ac.at/publications/tuw-137414.pdf

Koutromanos, G., Sofos, A., \& Avraamidou, L. (2015). The use of augmented reality games in education: A review of the literature. Educational Media International, 52(4), 253-271. https://doi.org/10.1080/09523987.2015.1125988

Laine, T. H. (2018). Mobile educational augmented reality games: A systematic literature review and two case studies. Computers, 7(1), 19. https://doi.org/10.3390/computers7010019

Lee, K. (2012). Augmented Reality in Education and Training. TechTrends, 56(2), 13-21. https://doi.org/10.1007/s11528-012-0559-3

Li, Jingwei, Antonenko, P., \& Wang, J. (2019). Trends and issues in multimedia learning research in 19962016: A bibliometric analysis. Educational Research Review, 28, 100282. https://doi.org/10.1016/j.edurev.2019.100282

Li, Jingya, van der Spek, E. D., Feijs, L., Wang, F., \& Hu, J. (2017). Augmented Reality Games for Learning: A Literature Review. In N. Streitz \& P. Markopoulos (Eds.), Distributed, Ambient and Pervasive Interactions (pp. 612-626). Springer International Publishing. https://doi.org/10.1007/978-3-31958697-7_46

López, J., Moreno-Guerrero, A.-J., López Núñez, J. A., \& Pozo Sánchez, S. (2019). Analysis of the Productive, Structural, and Dynamic Development of Augmented Reality in Higher Education Research on the Web of Science. Applied Sciences, 9(24), 5306. https://doi.org/10.3390/app9245306

Masood, T., \& Egger, J. (2019). Augmented reality in support of Industry 4.0-Implementation challenges and success factors. Robotics and Computer-Integrated Manufacturing, 58, 181-195. https://doi.org/10.1016/j.rcim.2019.02.003

McCarthy, C., \& Uppot, R. (2019). Advances in Virtual and Augmented Reality-Exploring the Role in Healthcare Education. Journal of Radiology Nursing, 38(2), 104-105. https://doi.org/10.1016/j.jradnu.2019.01.008

Milgram, P., Takemura, H., Utsumi, A., \& Kishino, F. (1994). Augmented Reality: A Class of Displays on the Reality-Virtuality Continuum. SPIE Proceedings Vol. 2351: Telemanipulator and Telepresence Technologies, 282-292. https://doi.org/10.1117/12.197321

Ojino, R., \& Mich, L. (2018). Mobile Aapplications in University Education: The case of Kenya. Journal of ELearning and Knowledge Society, 14(1), 109-123. https://doi.org/10.20368/1971-8829/1369

Oliveira, O., Silva, F., Juliani, F., Ferreira, L., \& Nunhes, T. (2019). Bibliometric Method for Mapping the Stateof-the-Art and Identifying Research Gaps and Trends in Literature: An Essential Instrument to Support the Development of Scientific Projects. Scientometrics Recent Advances. https://doi.org/10.5772/intechopen.85856

Pellas, N., Fotaris, P., Kazanidis, I., \& Wells, D. (2019). Augmenting the learning experience in primary and secondary school education: A systematic review of recent trends in augmented reality game-based learning. Virtual Reality, 23(4), 329-346. https://doi.org/10.1007/s10055-018-0347-2 
Pons, J. de P. (2018). Digital technologies and their impact on Higher Education. The new mediations. RIEDRevista Iberoamericana de Educación a Distancia, 21(2), 83-95. https://doi.org/10.5944/ried.21.2.20733

Radu, I. (2014). Augmented reality in education: A meta-review and cross-media analysis. Personal and Ubiquitous Computing, 1-11. https://doi.org/10.1007/s00779-013-0747-y

Rusiñol, M., Chazalon, J., \& Diaz-Chito, K. (2018). Augmented songbook: An augmented reality educational application for raising music awareness. Multimedia Tools and Applications, 77(11), 13773-13798. https://doi.org/10.1007/s11042-017-4991-4

Saltan, F., \& Arslan, Ö. (2017). The use of augmented reality in formal education: A scoping review. Eurasia Journal of Mathematics, Science and Technology Education, 13(2), 503-520. https://doi.org/10.12973/eurasia.2017.00628a

Saorin, J., Meier, C., de la Torre-Cantrero, J., Carbonell-Carrera, C., Melian-Diaz, D., \& Bonnet de Leon, A. (2017). Digital Competence: It's relation with the use and handling of 3D digital models and 3D printed 3D models. EDMETIC, 6(2), 28-46. https://doi.org/10.21071/edmetic.v6i2.6187

Sen, A., Chuen, C., \& Zay, A. (2018). Toward Smart Learning Environments: Affordances and Design Architecture of Augmented Reality (AR) Applications in Medical Education. En A. K. Somani, S. Srivastava, A. Mundra, \& S. Rawat (Eds.), Proceedings of First International Conference on Smart System, Innovations and Computing (pp. 843-861). Springer. https://doi.org/10.1007/978-981-105828-8_80

Sommerauer, P., \& Müller, O. (2014). Augmented reality in informal learning environments: A field experiment in a mathematics exhibition. Computers \& Education, 79, 59-68. https://doi.org/10.1016/j.compedu.2014.07.013

Squire, K., \& Klopfer, E. (2007). Augmented reality simulations on handheld computers. Journal of the Learning Sciences, 16(3), 371-413. https://doi.org/10.1080/10508400701413435

Sungkur, R. K., Panchoo, A., \& Bhoyroo, N. K. (2016). Augmented reality, the future of contextual mobile learning. Interactive Technology and Smart Education, 13(2), 123-146. https://doi.org/10.1108/ITSE07-2015-0017

Tekedere, H., \& Göker, H. (2016). Examining the effectiveness of augmented reality applications in education: A meta-analysis. International Journal of Environmental and Science Education, 11(16), 9469-9481.

Tobar-Muñoz, H., Baldiris, S., \& Fabregat, R. (2017). Augmented Reality Game-Based Learning: Enriching Students' Experience During Reading Comprehension Activities. Journal of Educational Computing Research, 55(7), 901-936. https://doi.org/10.1177/0735633116689789

Tzimas, E., Vosniakos, G.-C., \& Matsas, E. (2019). Machine tool setup instructions in the smart factory using augmented reality: A system construction perspective. International Journal on Interactive Design and Manufacturing, 13(1), 121-136. https://doi.org/10.1007/s12008-018-0470-z

Wang, X., Van Elzakker, C. P. J. M., \& Kraak, M.-J. (2017). Conceptual design of a mobile application for geography fieldwork learning. ISPRS International Journal of Geo-Information, 6(11), 355. https://doi.org/10.3390/ijgi6110355

Wei, G. (2019). A Bibliometric Analysis of the Top Five Economics Journals During 2012-2016. Journal of Economic Surveys, 33(1), 25-59. https://doi.org/10.1111/joes.12260

Wojciechowski, R., \& Cellary, W. (2013). Evaluation of learners' attitude toward learning in ARIES augmented $\begin{array}{llll}\text { reality environments. Computers \& } & \text { 5ducation, 68, } 585 .\end{array}$ https://doi.org/10.1016/j.compedu.2013.02.014 
Wu, H.-K., Lee, S. W.-Y., Chang, H.-Y., \& Liang, J.-C. (2013). Current status, opportunities and challenges of augmented reality in education. Computers \& Education, 62, 41-49. https://doi.org/10.1016/j.compedu.2012.10.024

Yang, G., \& Wu, L. (2017). Trend in $\mathrm{H}_{2} \mathrm{~S}$ Biology and Medicine Research-A Bibliometric Analysis. Molecules (Basel, Switzerland), 22(12), 2087. https://doi.org/10.3390/molecules22122087

Yilmaz, R. M. (2016). Educational magic toys developed with augmented reality technology for early childhood education. Computers in Human Behavior, 54(4), 240-248. https://doi.org/10.1016/j.chb.2015.07.040

Zyoud, S. H., Sweileh, W. M., Awang, R., \& Al-Jabi, S. W. (2018). Global trends in research related to social media in psychology: Mapping and bibliometric analysis. International Journal of Mental Health Systems, 12(1), 4. https://doi.org/10.1186/s13033-018-0182-6

Correspondence: Jorge Bacca-Acosta, Fundación Universitaria Konrad Lorenz, Faculty of Mathematics and Engineering, Bogotá, Colombia. E-mail: jorge.bacca@konradlorenz.edu.co 


\section{APPENDIX A}

\section{Systematic Reviews and Surveys on AR in education}

Table A1. Systematic literature reviews and meta-analysis conducted in AR in education

Type of paper: J=journal article, $\mathrm{C}=$ conference, $\mathrm{BC}=$ book chapter; Type of review: $\mathrm{R}=$ systematic literature review, $\mathrm{MA}=$ meta-analysis

\begin{tabular}{|c|c|c|c|c|c|c|c|c|c|}
\hline$\overline{\#}$ & $\begin{array}{c}\text { Type } \\
\text { of } \\
\text { paper }\end{array}$ & Title & $\begin{array}{c}\text { Year of } \\
\text { publication }\end{array}$ & Source of publication & $\begin{array}{c}\text { Type } \\
\text { of } \\
\text { review }\end{array}$ & Main topic & $\begin{array}{l}\text { Number } \\
\text { of } \\
\text { studies }\end{array}$ & $\begin{array}{l}\text { Type of } \\
\text { papers } \\
\text { reviewed }\end{array}$ & Coverage \\
\hline 1 & $\mathrm{~J}$ & $\begin{array}{c}\text { Augmented reality in STEM } \\
\text { education: a systematic review }\end{array}$ & 2020 & $\begin{array}{l}\text { Interactive Learning } \\
\text { Environments }\end{array}$ & $\mathrm{R}$ & $\begin{array}{l}\text { Impact of AR } \\
\text { on STEM } \\
\text { education }\end{array}$ & 42 & $\begin{array}{l}\text { Journal } \\
\text { articles }\end{array}$ & $\begin{array}{l}\text { Until } \\
2019\end{array}$ \\
\hline 2 & $\mathrm{~J}$ & $\begin{array}{l}\text { Perspectives on how to evaluate } \\
\text { augmented reality technology tools } \\
\text { for education: a systematic review }\end{array}$ & 2019 & $\begin{array}{l}\text { Journal of the Brazilian } \\
\text { Computer Society }\end{array}$ & $\mathrm{R}$ & $\begin{array}{c}\text { Impact of AR in } \\
\text { the learning } \\
\text { process }\end{array}$ & 45 & $\begin{array}{c}\text { Journal and } \\
\text { Conference } \\
\text { papers }\end{array}$ & $\begin{array}{l}2009- \\
2017\end{array}$ \\
\hline 3 & $\mathrm{~J}$ & $\begin{array}{l}\text { Meta-analysis of the impact of } \\
\text { Augmented Reality on students' } \\
\text { learning gains }\end{array}$ & 2019 & $\begin{array}{l}\text { Educational Research } \\
\text { Review }\end{array}$ & $\mathrm{MA}$ & $\begin{array}{l}\text { Impact of AR } \\
\text { on students' } \\
\text { learning gains }\end{array}$ & 64 & $\begin{array}{l}\text { Journal } \\
\text { Articles }\end{array}$ & $\begin{array}{l}2010- \\
2018\end{array}$ \\
\hline 4 & $\mathrm{~J}$ & $\begin{array}{c}\text { Augmented and virtual reality in } \\
\text { dental medicine: A systematic } \\
\text { review }\end{array}$ & 2019 & $\begin{array}{l}\text { Computers in Biology } \\
\text { and Medicine }\end{array}$ & $\mathrm{R}$ & $\begin{array}{l}\text { AR in dental } \\
\text { medicine }\end{array}$ & 16 & $\begin{array}{l}\text { Journal and } \\
\text { Conference } \\
\text { papers }\end{array}$ & $\begin{array}{l}\text { Until } \\
2018\end{array}$ \\
\hline 5 & C & $\begin{array}{l}\text { Augmented Reality Experiences in } \\
\text { Informal Education }\end{array}$ & 2019 & $\begin{array}{l}2018 \text { IEEE International } \\
\text { Conference on Teaching, } \\
\text { Assessment, and } \\
\text { Learning for Engineering } \\
\text { (TALE) }\end{array}$ & 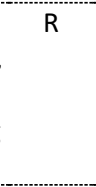 & $\begin{array}{l}\text { AR in informal } \\
\text { education }\end{array}$ & 18 & $\begin{array}{l}\text { Journal } \\
\text { Articles }\end{array}$ & $\begin{array}{l}2010- \\
2017\end{array}$ \\
\hline 6 & $\mathrm{~J}$ & $\begin{array}{c}\text { Systematic review and meta-analysis } \\
\text { of augmented reality in educational } \\
\text { settings }\end{array}$ & 2019 & IEEE Virtual Reality & $\mathrm{MA}$ & $A R$ in education & 61 & $\begin{array}{l}\text { Journal } \\
\text { Articles }\end{array}$ & $\begin{array}{l}2012- \\
2018\end{array}$ \\
\hline 7 & $\mathrm{~J}$ & $\begin{array}{l}\text { Research trends in the use of } \\
\text { augmented reality in science }\end{array}$ & 2019 & Computers \& Education & $\mathrm{R}$ & $\begin{array}{l}\text { AR in science } \\
\text { learning }\end{array}$ & 62 & $\begin{array}{l}\text { Journal } \\
\text { articles }\end{array}$ & $\begin{array}{l}2013- \\
2018\end{array}$ \\
\hline
\end{tabular}

education: Content and bibliometric mapping analysis

8 J How Mobile Augmented Reality is 2019 Creative Education R AR in education 57 Journal and 2011Applied in Education? A Systematic conference 1018 Review

9 J The Effect of Augmented Reality 2018 Eurasian Journal of MA AR in education $16 \quad$ Journal 2007 Applications in the Learning Process: $\quad$ Educational Research articles 2017

A Meta-Analysis Study

10 J A Systematic Review of 10 Years of 2018 Frontiers in Robotics and R User studies 291 Journal and 2005Augmented Reality Usability Studies: $\quad$ Al with AR Conference 2014 2005 to 2014

11 J Augmented reality for STEM learning 2018 Computers \& Education R AR in STEM $28 \quad$ Journal $2010-$ A Systematic Review

12 J Applications of Augmented Reality in 2018 Journal of Science R AR in informal 17 Informal Science Learning Sites: a $\quad$ Education and science Review Technologies education

13 J Augmenting the learning experience $2018 \quad$ Virtual Reality $\quad$ AR game-based 21 Journal 2012 in Primary and Secondary school learning 2017 education: A systematic review of recent trends in augmented reality (ARGBL) game-based learning

\begin{tabular}{|c|c|c|c|c|c|c|c|c|c|}
\hline 14 & J & $\begin{array}{c}\text { Trends in Educational Augmented } \\
\text { Reality Studies: A Systematic Review }\end{array}$ & 2018 & $\begin{array}{l}\text { Malaysian Online Journal } \\
\text { of Educational } \\
\text { Technology }\end{array}$ & $\mathrm{R}$ & AR in education & 105 & $\begin{array}{l}\text { Journal } \\
\text { articles }\end{array}$ & $\begin{array}{r}2011- \\
2016\end{array}$ \\
\hline 15 & $\mathrm{~J}$ & $\begin{array}{l}\text { Using sensors and augmented reality } \\
\text { to train apprentices using recorded } \\
\text { expert performance: A systematic } \\
\text { literature review }\end{array}$ & 2018 & $\begin{array}{l}\text { Educational Research } \\
\text { Review }\end{array}$ & $\mathrm{R}$ & $\begin{array}{l}\text { AR and sensors } \\
\text { in training }\end{array}$ & 78 & $\begin{array}{l}\text { Journal and } \\
\text { Conference } \\
\text { papers }\end{array}$ & $\begin{array}{l}2014- \\
2016\end{array}$ \\
\hline 16 & $\mathrm{~J}$ & $\begin{array}{l}\text { The state of immersive technology } \\
\text { research: A literature analysis }\end{array}$ & 2018 & $\begin{array}{l}\text { Computers in Human } \\
\text { Behavior }\end{array}$ & $\mathrm{R}$ & $\begin{array}{c}\text { AR as } \\
\text { immersive } \\
\text { technology }\end{array}$ & 54 & $\begin{array}{l}\text { Journal } \\
\text { papers }\end{array}$ & $\begin{array}{l}2010- \\
2017\end{array}$ \\
\hline 17 & J & $\begin{array}{c}\text { Mobile Educational Augmented } \\
\text { Reality Games: A Systematic } \\
\text { Literature Review and Two Case } \\
\text { Studies }\end{array}$ & 2018 & Computers & $\mathrm{R}$ & $\begin{array}{l}\text { Educational } \\
\text { mobile AR } \\
\text { games }\end{array}$ & 44 & - & $\begin{array}{l}2012- \\
2017\end{array}$ \\
\hline
\end{tabular}


Avila-Garzon et al. / Contemporary Educational Technology, 2021, 13(3), ep302

\begin{tabular}{|c|c|c|c|c|c|c|c|c|c|}
\hline$\#$ & $\begin{array}{l}\text { Type } \\
\text { of } \\
\text { paper }\end{array}$ & Title & $\begin{array}{c}\text { Year of } \\
\text { publication }\end{array}$ & Source of publication & $\begin{array}{l}\text { Type } \\
\text { of } \\
\text { review }\end{array}$ & Main topic & $\begin{array}{l}\text { Number } \\
\text { of } \\
\text { studies }\end{array}$ & $\begin{array}{l}\text { Type of } \\
\text { papers } \\
\text { reviewed }\end{array}$ & Coverage \\
\hline 18 & $\mathrm{~J}$ & $\begin{array}{l}\text { A Systematic Review of Learning } \\
\text { through Mobile Augmented Reality }\end{array}$ & 2018 & $\begin{array}{l}\text { International Journal of } \\
\text { Interactive Mobile } \\
\text { Technologies }\end{array}$ & $\mathrm{R}$ & AR in education & 77 & $\begin{array}{c}\text { Journal and } \\
\text { Conference } \\
\text { papers }\end{array}$ & $\begin{array}{l}2000- \\
2017\end{array}$ \\
\hline 19 & C & $\begin{array}{l}\text { Toward smart learning } \\
\text { environments: Affordances and } \\
\text { design architecture of augmented } \\
\text { reality (AR) applications in medical } \\
\text { education }\end{array}$ & 2018 & $\begin{array}{l}\text { Proceedings of First } \\
\text { International Conference } \\
\text { on Smart System, } \\
\text { Innovations and } \\
\text { Computing }\end{array}$ & $\mathrm{R}$ & $\begin{array}{l}\text { AR in medical } \\
\text { education }\end{array}$ & 25 & Journals & - \\
\hline 20 & $\mathrm{C}$ & $\begin{array}{c}\text { Augmented Reality For Teaching And } \\
\text { Learning - A Literature Review On } \\
\text { Theoretical And Empirical } \\
\text { Foundations }\end{array}$ & 2018 & Research Papers & $\mathrm{R}$ & $\begin{array}{l}\text { Theoretical and } \\
\text { Empirical } \\
\text { foundations of } \\
\text { AR in education }\end{array}$ & 36 & $\begin{array}{c}\text { Journal and } \\
\text { Conference } \\
\text { papers }\end{array}$ & - \\
\hline 21 & J & $\begin{array}{c}\text { Augmented Reality applications in } \\
\text { education to improve teaching - } \\
\text { learning processes: a systematic } \\
\text { review }\end{array}$ & 2018 & Espacios & $\mathrm{R}$ & AR in education & 50 & $\begin{array}{l}\text { Journal and } \\
\text { Conference } \\
\text { papers }\end{array}$ & $\begin{array}{l}2013- \\
2018\end{array}$ \\
\hline 22 & $\mathrm{~J}$ & $\begin{array}{l}\text { Exploring mobile mixed reality in } \\
\text { healthcare higher education: A } \\
\text { systematic review }\end{array}$ & 2018 & $\begin{array}{l}\text { Research in Learning } \\
\text { Technology }\end{array}$ & $\mathrm{R}$ & $\begin{array}{l}\text { MR in } \\
\text { Healthcare } \\
\text { higher } \\
\text { education }\end{array}$ & 18 & $\begin{array}{l}\text { Journal } \\
\text { articles }\end{array}$ & $\begin{array}{l}\text { All years } \\
\text { until } \\
2018\end{array}$ \\
\hline 23 & $\mathrm{~J}$ & $\begin{array}{l}\text { Advantages and challenges } \\
\text { associated with augmented reality } \\
\text { for education: A systematic review } \\
\text { of the literature }\end{array}$ & 2017 & $\begin{array}{l}\text { Educational Research } \\
\text { Review }\end{array}$ & $\mathrm{R}$ & $A R$ in education & 68 & Journal & $\begin{array}{l}\text { Until } \\
2015\end{array}$ \\
\hline 24 & $\mathrm{C}$ & $\begin{array}{l}\text { Augmented reality applications for } \\
\text { education: Five directions for future } \\
\text { research }\end{array}$ & 2017 & $\begin{array}{c}\text { Lecture Notes in } \\
\text { Computer Science } \\
\text { (International } \\
\text { Conference on } \\
\text { Augmented Reality, } \\
\text { Virtual Reality and } \\
\text { Computer Graphics) }\end{array}$ & $\mathrm{R}$ & AR in Education & $\begin{array}{l}50 \\
\text { articles }\end{array}$ & $\begin{array}{l}\text { Journal } \\
\text { articles and } \\
\text { Conference } \\
\text { papers }\end{array}$ & $\begin{array}{l}2011- \\
2017\end{array}$ \\
\hline 25 & $\mathrm{C}$ & $\begin{array}{l}\text { Augmented Reality Games for } \\
\text { Learning: A Literature Review }\end{array}$ & 2017 & $\begin{array}{l}\text { International Conference } \\
\text { on Distributed, Ambient, } \\
\text { and Pervasive } \\
\text { Interactions }\end{array}$ & $\mathrm{R}$ & $\begin{array}{l}\text { AR games for } \\
\text { learning }\end{array}$ & 26 & $\begin{array}{c}\text { Journal and } \\
\text { Conference } \\
\text { papers }\end{array}$ & - \\
\hline 26 & C & $\begin{array}{l}\text { A systematic review of Augmented } \\
\text { Reality game-based applications in } \\
\text { primary education }\end{array}$ & 2017 & $\begin{array}{c}\text { 11th European } \\
\text { Conference on Games } \\
\text { Based Learning }\end{array}$ & $\mathrm{R}$ & $\begin{array}{l}\text { AR game-based } \\
\text { learning } \\
\text { (ARGBL) }\end{array}$ & 17 & $\begin{array}{l}\text { Journal } \\
\text { articles }\end{array}$ & $\begin{array}{l}2012- \\
2017\end{array}$ \\
\hline 27 & J & $\begin{array}{l}\text { Key themes in mobile learning: } \\
\text { Prospects for learner-generated } \\
\text { learning through AR and VR }\end{array}$ & 2017 & $\begin{array}{l}\text { Australasian Journal of } \\
\text { Educational Technology }\end{array}$ & $\mathrm{R}$ & $\begin{array}{l}\text { Learner- } \\
\text { generated } \\
\text { learning in AR } \\
\text { and VR }\end{array}$ & 328 & $\begin{array}{l}\text { Journal and } \\
\text { Conference } \\
\text { papers }\end{array}$ & $\begin{array}{l}2010- \\
2016\end{array}$ \\
\hline 28 & J & $\begin{array}{l}\text { A comprehensive survey of } \\
\text { augmented reality assembly } \\
\text { research }\end{array}$ & 2016 & $\begin{array}{l}\text { Advances in } \\
\text { Manufacturing }\end{array}$ & $\mathrm{R}$ & $\begin{array}{l}\text { AR in assembly } \\
\text { processes }\end{array}$ & 91 & - & $\begin{array}{l}2005- \\
2015\end{array}$ \\
\hline 29 & BC & $\begin{array}{l}\text { A review of using Augmented Reality } \\
\text { in Education from } 2011 \text { to } 2016\end{array}$ & 2016 & $\begin{array}{l}\text { Innovations in Smart } \\
\text { Learning }\end{array}$ & $\mathrm{R}$ & AR in education & $\begin{array}{c}55 \\
\text { articles }\end{array}$ & $\begin{array}{l}\text { Journal } \\
\text { articles }\end{array}$ & $\begin{array}{l}2011- \\
2016\end{array}$ \\
\hline 30 & $\mathrm{~J}$ & $\begin{array}{l}\text { Examining the Effectiveness of } \\
\text { Augmented Reality Applications in } \\
\text { Education: A Meta-Analysis }\end{array}$ & 2016 & $\begin{array}{c}\text { International Journal of } \\
\text { Environmental \& Science } \\
\text { Education }\end{array}$ & $\mathrm{R}$ & $A R$ in education & 17 & $\begin{array}{l}\text { Journal } \\
\text { articles }\end{array}$ & $\begin{array}{l}2005- \\
2015\end{array}$ \\
\hline 31 & $\mathrm{~J}$ & $\begin{array}{l}\text { The Use of Augmented Reality in } \\
\text { Formal Education: A Scoping Review }\end{array}$ & 2016 & $\begin{array}{l}\text { Eurasia Journal of } \\
\text { Mathematics, Science \& } \\
\text { Technology Education }\end{array}$ & $\mathrm{R}$ & $\begin{array}{l}\text { AR in formal } \\
\text { education }\end{array}$ & 23 & - & $\begin{array}{l}2012- \\
2016\end{array}$ \\
\hline 32 & J & $\begin{array}{c}\text { Evaluation of quality and } \\
\text { personalisation of VR/AR/MR } \\
\text { learning systems }\end{array}$ & 2016 & $\begin{array}{l}\text { Behavior \& Information } \\
\text { Technology }\end{array}$ & $\mathrm{R}$ & $\begin{array}{l}\text { Evaluation of } \\
\text { quality and } \\
\text { personalization } \\
\text { in MR }\end{array}$ & 33 & $\begin{array}{c}\text { Journal and } \\
\text { Conference } \\
\text { papers }\end{array}$ & $\begin{array}{l}2014- \\
2016\end{array}$ \\
\hline 33 & J & $\begin{array}{l}\text { Systematic review on the } \\
\text { effectiveness of augmented reality } \\
\text { applications in medical training }\end{array}$ & 2016 & Surgical Endoscopy & $\mathrm{R}$ & $\begin{array}{l}\text { AR in medical } \\
\text { training }\end{array}$ & 27 & $\begin{array}{l}\text { Journal } \\
\text { articles }\end{array}$ & $\begin{array}{l}\text { Until } \\
2015\end{array}$ \\
\hline 34 & J & $\begin{array}{l}\text { A Review of Research on Augmented } \\
\text { Reality in Education: Advantages and } \\
\text { Applications }\end{array}$ & 2015 & $\begin{array}{l}\text { International Education } \\
\text { Studies }\end{array}$ & $\mathrm{R}$ & AR in education & 9 & $\begin{array}{c}\text { Journal and } \\
\text { Conference } \\
\text { papers }\end{array}$ & $\begin{array}{l}\text { Until } \\
2014\end{array}$ \\
\hline
\end{tabular}


Avila-Garzon et al. / Contemporary Educational Technology, 2021, 13(3), ep302

\begin{tabular}{|c|c|c|c|c|c|c|c|c|c|}
\hline$\#$ & $\begin{array}{l}\text { Type } \\
\text { of } \\
\text { paper }\end{array}$ & Title & $\begin{array}{c}\text { Year of } \\
\text { publication }\end{array}$ & Source of publication & $\begin{array}{c}\text { Type } \\
\text { of } \\
\text { review }\end{array}$ & Main topic & $\begin{array}{l}\text { Number } \\
\text { of } \\
\text { studies }\end{array}$ & $\begin{array}{l}\text { Type of } \\
\text { papers } \\
\text { reviewed }\end{array}$ & Coverage \\
\hline 35 & $C$ & $\begin{array}{c}\text { Benefits of Augmented Reality in } \\
\text { Educational Environments - A } \\
\text { Systematic Literature Review }\end{array}$ & 2015 & $\begin{array}{c}\text { 12th International } \\
\text { Conference on } \\
\text { Wirtschaftsinformatik }\end{array}$ & $\mathrm{R}$ & AR in education & 25 & $\begin{array}{c}\text { Journal and } \\
\text { Conference } \\
\text { papers }\end{array}$ & - \\
\hline 36 & $\mathrm{~J}$ & $\begin{array}{l}\text { A Systematic Literature Review of } \\
\text { Factors Influencing Acceptance on } \\
\text { Mixed Reality Technology }\end{array}$ & 2015 & $\begin{array}{l}\text { ARPN Journal of } \\
\text { Engineering and Applied } \\
\text { Sciences }\end{array}$ & $\mathrm{R}$ & $\begin{array}{l}\text { Acceptance of } \\
\text { Mixed reality }\end{array}$ & 26 & $\begin{array}{c}\text { Journals and } \\
\text { Conference } \\
\text { papers }\end{array}$ & $\begin{array}{l}2005- \\
2015\end{array}$ \\
\hline 37 & C & $\begin{array}{c}\text { Augmented Reality In E-Learning } \\
\text { Review of Prototype Designs For } \\
\text { Usability Evaluation }\end{array}$ & 2015 & $\begin{array}{l}2015 \text { International } \\
\text { Conference on } \\
\text { Communication, } \\
\text { Information \& } \\
\text { Computing Technology } \\
\text { (ICCICT) }\end{array}$ & $\mathrm{MA}$ & $\begin{array}{l}\text { Educational } \\
\text { impact of } A R\end{array}$ & 4 & $\begin{array}{l}\text { Journal and } \\
\text { Conference } \\
\text { papers }\end{array}$ & - \\
\hline 38 & $\mathrm{~J}$ & $\begin{array}{c}\text { The use of augmented reality games } \\
\text { in education: a review of the } \\
\text { literature }\end{array}$ & 2015 & $\begin{array}{l}\text { Educational Media } \\
\text { International }\end{array}$ & $\mathrm{R}$ & $\begin{array}{l}\text { AR games in } \\
\text { education }\end{array}$ & 7 & $\begin{array}{l}\text { Journal } \\
\text { Articles }\end{array}$ & $\begin{array}{l}2000- \\
2014\end{array}$ \\
\hline 39 & C & $\begin{array}{c}\text { Collaborative Augmented Reality in } \\
\text { Education: A Review }\end{array}$ & 2014 & $\begin{array}{c}2014 \text { International } \\
\text { Conference on Teaching } \\
\text { and Learning in } \\
\text { Computing and } \\
\text { Engineering (LaTiCE) }\end{array}$ & $\mathrm{R}$ & $\begin{array}{l}\text { Collaborative } \\
\text { AR in education }\end{array}$ & 10 & $\begin{array}{l}\text { Journal and } \\
\text { Conference } \\
\text { papers }\end{array}$ & $\begin{array}{l}2000- \\
2013\end{array}$ \\
\hline 40 & $\mathrm{~J}$ & $\begin{array}{l}\text { Augmented reality in healthcare } \\
\text { education: an integrative review }\end{array}$ & 2014 & PeerJ & $\mathrm{R}$ & $\begin{array}{l}\text { AR in } \\
\text { healthcare } \\
\text { education }\end{array}$ & 25 & $\begin{array}{c}\text { Journal and } \\
\text { Conference } \\
\text { papers }\end{array}$ & $\begin{array}{l}\text { Until } \\
2012\end{array}$ \\
\hline 41 & $\mathrm{~J}$ & $\begin{array}{l}\text { Review of Augmented Paper } \\
\text { Systems in Education: An } \\
\text { Orchestration Perspective }\end{array}$ & 2014 & $\begin{array}{l}\text { Journal of Educational } \\
\text { Technology and Scoiety }\end{array}$ & $\mathrm{R}$ & $\begin{array}{l}\text { Augmented } \\
\text { Paper systems }\end{array}$ & 40 & $\begin{array}{c}\text { Journal and } \\
\text { Conference } \\
\text { papers }\end{array}$ & - \\
\hline 42 & $\mathrm{~J}$ & $\begin{array}{c}\text { Augmented Reality Learning } \\
\text { Experiences: Survey of Prototype } \\
\text { Design and Evaluation }\end{array}$ & 2014 & $\begin{array}{l}\text { IEEE Transactions on } \\
\text { Learning Technologies }\end{array}$ & $\mathrm{R}, \mathrm{MA}$ & AR in education & $\begin{array}{l}87 \text { for } \\
\text { review - } \\
7 \text { for } \\
\text { meta- } \\
\text { analysis }\end{array}$ & $\begin{array}{l}\text { Journal and } \\
\text { Conference } \\
\text { papers }\end{array}$ & $\begin{array}{l}\text { Until } \\
2012\end{array}$ \\
\hline 43 & $\mathrm{~J}$ & & 2014 & $\begin{array}{l}\text { Educational Technology } \\
\text { \& Society }\end{array}$ & $\mathrm{R}$ & AR in education & 32 & $\begin{array}{l}\text { Journal } \\
\text { articles }\end{array}$ & $\begin{array}{l}2003- \\
2013\end{array}$ \\
\hline 44 & $\mathrm{~J}$ & $\begin{array}{l}\text { Augmented Reality in Education: a } \\
\text { meta-review and cross media } \\
\text { analysis }\end{array}$ & 2014 & $\begin{array}{l}\text { Personal and Ubiquitous } \\
\text { Computing }\end{array}$ & $\mathrm{R}$ & AR in education & 26 & $\begin{array}{c}\text { Journal and } \\
\text { Conference } \\
\text { papers }\end{array}$ & - \\
\hline 45 & $\mathrm{~J}$ & $\begin{array}{l}\text { Augmented Reality in built } \\
\text { environment: Classification and } \\
\text { implications for future research }\end{array}$ & 2013 & $\begin{array}{l}\text { Automation in } \\
\text { Construction }\end{array}$ & $\mathrm{R}$ & $\begin{array}{l}\text { AR in bult } \\
\text { environments }\end{array}$ & 120 & $\begin{array}{c}\text { Journal and } \\
\text { Conference } \\
\text { papers }\end{array}$ & $\begin{array}{l}2005- \\
2011\end{array}$ \\
\hline
\end{tabular}




\section{APPENDIX B}

\section{Systematic Reviews and Surveys on AR in education}

Table A2. Surveys on AR in education

Type of paper: J=journal article, $C=$ conference paper, $B C=$ book chapter

\begin{tabular}{|c|c|c|c|c|c|}
\hline \# & $\begin{array}{l}\text { Type of } \\
\text { paper }\end{array}$ & Title & $\begin{array}{c}\text { Year of } \\
\text { publication }\end{array}$ & Source of publication & Main topic \\
\hline 1 & $\mathrm{~J}$ & A review on augmented reality technology & 2018 & $\begin{array}{l}\text { International Journal of Emerging } \\
\text { Research in Management and } \\
\text { Technology (IJERMT) }\end{array}$ & $\begin{array}{l}\text { General survey of } \\
\text { AR }\end{array}$ \\
\hline 2 & C & $\begin{array}{l}\text { Applications of Augmented Reality in Emerging } \\
\text { Health Diagnostics: A Survey }\end{array}$ & 2018 & $\begin{array}{l}2018 \text { International Conference on } \\
\text { Automation and Computational } \\
\text { Engineering }\end{array}$ & AR in healthcare \\
\hline 3 & C & $\begin{array}{l}\text { A Survey of Pedagogical Affordances of Augmented } \\
\text { and Virtual Realities Technologies in loT- Based }\end{array}$ & 2018 & $\begin{array}{c}\text { Colloquium in Information Science and } \\
\text { Technology - CIST }\end{array}$ & $\begin{array}{l}\text { Pedagogical } \\
\text { affordances of AR }\end{array}$ \\
\hline
\end{tabular}

\begin{tabular}{|c|c|c|c|c|c|}
\hline \multicolumn{6}{|c|}{ Classroom } \\
\hline 4 & C & $\begin{array}{l}\text { Experiential learning through Virtual and } \\
\text { Augmented Reality in Higher Education }\end{array}$ & 2018 & $\begin{array}{c}\text { ICETM 2018: Proceedings of the } 2018 \\
\text { International Conference on Education } \\
\text { Technology Management }\end{array}$ & $\begin{array}{l}A R \text { and } V R \text { in } \\
\text { experiential } \\
\text { learning }\end{array}$ \\
\hline 5 & C & Emerging Trends in Augmented Reality Games & 2018 & $\begin{array}{l}2018 \text { International Conference on } \\
\text { Computing, Mathematics and } \\
\text { Engineering Technologies }\end{array}$ & AR games \\
\hline 6 & J & $\begin{array}{l}\text { A Survey of Augmented, Virtual, and Mixed } \\
\text { Realityfor Cultural Heritage }\end{array}$ & 2018 & $\begin{array}{c}\text { ACM Journal on Computing and Cultural } \\
\text { Heritage }\end{array}$ & $\begin{array}{l}\mathrm{XR} \text { in cultural } \\
\text { Heritage }\end{array}$ \\
\hline 7 & C & $\begin{array}{l}\text { Educational augmented reality systems: benefits of } \\
\text { implementation and government support }\end{array}$ & 2018 & $\begin{array}{l}\text { 4th International Conference of the } \\
\text { Virtual and Augmented Reality in } \\
\text { Education, VARE } 2018\end{array}$ & AR in education \\
\hline 8 & J & Virtual Technologies Trends in Education & 2017 & $\begin{array}{l}\text { Eurasia Journal of Mathematics, Science } \\
\text { \& Technology education }\end{array}$ & $\begin{array}{l}A R \text { and } V R \text { in } \\
\text { education }\end{array}$ \\
\hline 9 & J & $\begin{array}{l}\text { Utilizing virtual and augmented reality for } \\
\text { educational and clinical enhancements in } \\
\text { neurosurgery }\end{array}$ & 2017 & Journal of Clinical Neuroscience & $\begin{array}{l}\text { AR for education in } \\
\text { Neurosurgery }\end{array}$ \\
\hline 10 & C & $\begin{array}{l}\text { Interaction with Three Dimensional Objects on } \\
\text { Diverse Input and Output Devices: A Survey }\end{array}$ & 2017 & $\begin{array}{l}\text { International Conference on Human- } \\
\text { Computer Interaction - HCl } 2017\end{array}$ & $\begin{array}{l}\text { Interaction } \\
\text { techniques in AR } \\
\text { and VR }\end{array}$ \\
\hline 11 & $\mathrm{BC}$ & Application of Mobile AR in E-learning: An Overview & 2016 & Transactions on Edutainment XI & $\begin{array}{l}\text { Applications of AR } \\
\text { in education }\end{array}$ \\
\hline 12 & J & $\begin{array}{l}\text { Augmented Reality in Medical Education and } \\
\text { Training }\end{array}$ & 2016 & $\begin{array}{l}\text { Journal of Electronic Resources in } \\
\text { Medical Libraries }\end{array}$ & $\begin{array}{l}\text { AR in medical } \\
\text { education }\end{array}$ \\
\hline 13 & C & Application of Mobile AR in E-learning: An Overview & 2015 & $\begin{array}{l}\text { Transactions on Edutainment XI / } \\
\text { Lecture Notes in Computer Science }\end{array}$ & AR in e-learning \\
\hline 14 & $\mathrm{~J}$ & $\begin{array}{c}\text { Challenges, Opportunities, and Future Trends of } \\
\text { Emerging Techniques for Augmented Reality-Based } \\
\text { Maintenance }\end{array}$ & 2015 & $\begin{array}{l}\text { IEEE Transactions on Emerging topics in } \\
\text { Computing }\end{array}$ & $A R$ in maintenance \\
\hline 15 & $\mathrm{~J}$ & The educational possibilities of Augmented Reality & 2015 & $\begin{array}{l}\text { NEW APPROACHES IN EDUCATIONAL } \\
\text { RESEARCH }\end{array}$ & $A R$ in \\
\hline 16 & c & $\begin{array}{c}\text { Challenges and Possibilities of Use of Augmented } \\
\text { Reality in Education - Case Study in Music } \\
\text { Education }\end{array}$ & 2015 & $\begin{array}{l}\text { International Conference on } \\
\text { Computational Science and Its } \\
\text { Applications }\end{array}$ & Music education \\
\hline 17 & J & Augmented Reality in education - cases, places and & 2014 & Educational Media International & Education \\
\hline 18 & $\mathrm{BC}$ & $\begin{array}{l}\text { Educational Tools: A Review of Interfaces of } \\
\text { Mobile-Augmented Reality (mAR) Applications }\end{array}$ & 2014 & $\begin{array}{l}\text { Innovations and Advances in } \\
\text { Computing, Informatics, Systems } \\
\text { Sciences, Networking and Engineering }\end{array}$ & AR interfaces \\
\hline 19 & C & $\begin{array}{l}\text { Augmented Reality Tools and Learning Practicein } \\
\text { Mobile-Learning }\end{array}$ & 2014 & $\begin{array}{l}\text { International Conference on Universal } \\
\text { Access in Human-Computer Interaction }\end{array}$ & $\begin{array}{l}\text { AR apps in } \\
\text { education }\end{array}$ \\
\hline 20 & C & $\begin{array}{l}\text { Augmented Reality: Applications, Challenges and } \\
\text { Future Trends }\end{array}$ & 2014 & $\begin{array}{c}\text { Proceedings of the 13th International } \\
\text { Conference on Applied Computer and } \\
\text { Applied Computational Science } \\
\text { (ACACOS '14) }\end{array}$ & General \\
\hline 21 & $\mathrm{~J}$ & $\begin{array}{l}\text { Rise of Augmented Reality: Current and Future } \\
\text { Application Areas }\end{array}$ & 2013 & $\begin{array}{l}\text { International Journal of Internet and } \\
\text { Distributed Systems }\end{array}$ & General \\
\hline 22 & J & $\begin{array}{l}\text { Augmented reality and mobile learning: The } \\
\text { state of the art }\end{array}$ & 2013 & $\begin{array}{l}\text { International Journal of Mobile and } \\
\text { Blended Learning }\end{array}$ & $\begin{array}{l}\text { Mobile AR and } \\
\text { Situated learning }\end{array}$ \\
\hline
\end{tabular}


Avila-Garzon et al. / Contemporary Educational Technology, 2021, 13(3), ep302

\begin{tabular}{|c|c|c|c|c|c|}
\hline$\#$ & $\begin{array}{l}\text { Type of } \\
\text { paper }\end{array}$ & Title & $\begin{array}{c}\text { Year of } \\
\text { publication }\end{array}$ & Source of publication & Main topic \\
\hline 23 & $\mathrm{~J}$ & & 2013 & $\begin{array}{l}\text { Journal of Science Education and } \\
\text { Technology }\end{array}$ & $\begin{array}{l}\text { AR in science } \\
\text { learning }\end{array}$ \\
\hline 24 & J & Augmented Reality in Education and Training & 2012 & TechTrends & AR in Education \\
\hline 25 & $\mathrm{~J}$ & Augmented Reality: A Review & 2012 & Medical Reference Services Quarterly & General \\
\hline 26 & $\mathrm{~J}$ & $\begin{array}{l}\text { Augmented reality technologies, systems and } \\
\text { applications }\end{array}$ & 2011 & Multimedia Tools and Applications & $\begin{array}{l}\text { AR Technologies } \\
\text { and Applications }\end{array}$ \\
\hline 27 & $\mathrm{~J}$ & $\begin{array}{l}\text { Augmented Reality: An Overview and Five } \\
\text { Directions for AR in Education }\end{array}$ & 2011 & $\begin{array}{l}\text { Journal of Educational Technology } \\
\text { Development and Exchange }\end{array}$ & AR applications \\
\hline 28 & $\mathrm{BC}$ & Augmented Reality: An Overview & 2011 & Handbook of Augmented reality & $\begin{array}{l}\text { AR technologies } \\
\text { and applications }\end{array}$ \\
\hline 29 & $\mathrm{~J}$ & $\begin{array}{l}\text { A Survey of Augmented Reality Technologies, } \\
\text { Applications and Limitations }\end{array}$ & 2010 & $\begin{array}{l}\text { The International Journal of Virtual } \\
\text { Reality }\end{array}$ & General \\
\hline 30 & $\mathrm{BC}$ & $\begin{array}{l}\text { A Useful Visualization Technique: A Literature } \\
\text { Review for Augmented Reality and its } \\
\text { Application, limitation \& future direction }\end{array}$ & 2009 & Visual Information Communication & $\begin{array}{l}\text { AR technologies } \\
\text { and Applications }\end{array}$ \\
\hline 31 & C & $\begin{array}{c}\text { Survey on Collaborative AR for Multi-user in } \\
\text { Urban Studies and Planning }\end{array}$ & 2009 & $\begin{array}{c}\text { International Conference on } \\
\text { Technologies for E-Learning and } \\
\text { Digital Entertainment }\end{array}$ & $\begin{array}{l}\text { Collaborative } A R \\
\text { for urban studies } \\
\text { and planning }\end{array}$ \\
\hline 32 & $\mathrm{~J}$ & $\begin{array}{l}\text { A survey of mobile and wireless technologies for } \\
\text { augmented reality systems }\end{array}$ & 2008 & $\begin{array}{l}\text { Computer animation and virtual } \\
\text { worlds }\end{array}$ & AR Technologies \\
\hline 33 & $\mathrm{~J}$ & Augmented Reality in Surgery & 2004 & Arch. Surg. & AR in Surgery \\
\hline
\end{tabular}

